\title{
Vmesniki in pretvorniki:
}

\section{laboratorijske vaje}

\author{
Avtorja:
}

dr. Iztok Kramberger

dr. Gregor Donaj

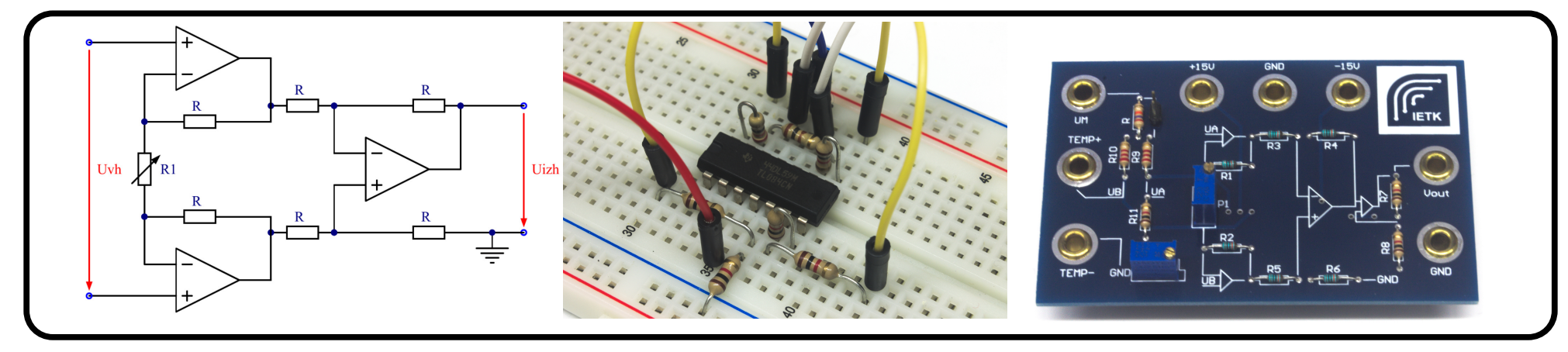



Vmesniki in pretvorniki: laboratorijske vaje 



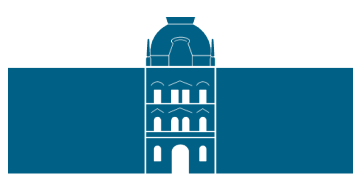

Univerzitetna založba

Univerze v Mariboru

Vmesniki in pretvorniki:

laboratorijske vaje

Avtorja:

dr. Iztok Kramberger

dr. Gregor Donaj

Maribor, januar 2018 
Naslov: Vmesniki in pretvorniki

Podnaslov: laboratorijske vaje

Avtorja: doc. dr. Iztok Kramberger (Univerza v Mariboru, Fakulteta za elektrotehniko, računalništvo in informatiko) in asist. dr. Gregor Donaj (Univerza v Mariboru, Fakulteta za elektrotehniko, računalništvo in informatiko)

Jazikovna recenzija: Darinka Verdonik

Tehnični urednik: asist. dr. Gregor Donaj (Univerza v Mariboru, Fakulteta za elektrotehniko, računalništvo in informatiko)

Grafične priloge: asist. dr. Gregor Donaj (Univerza v Mariboru, Fakulteta za elektrotehniko, računalništvo in informatiko)

Oblikovanje ovitka: asist. dr. Gregor Donaj (Univerza v Mariboru, Fakulteta za elektrotehniko, računalništvo in informatiko)

\section{Izdajateljica:}

Univerza v Mariboru, Fakulteta za elektrotehniko, računalništvo in informatiko Koroška cesta 46, 2000 Maribor, Slovenija tel. +386222070 00, faks +38622207272

http://feri.um.si, feri@um.si

\section{Založnik:}

Univerzitetna založba Univerze v Mariboru Slomškov trg 15, 2000 Maribor, Slovenija tel. +3862 2355276 , faks +38622523245 http://press.um.si, zalozba@um.si

Izdaja: Prva izdaja

Vrsta publikacije: Elektronska knjiga

Dostopno na: http://press.um.si/index.php/ump/catalog/book/313

Izid: Maribor, januar 2018 


\section{(c)(1)(9)}

(C)Avtorja. To delo je dosegljivo pod licenco Creative Commons

Priznanje avtorstva-Nekomercialno-Deljenje pod enakimi pogoji 4.0 Mednarodna

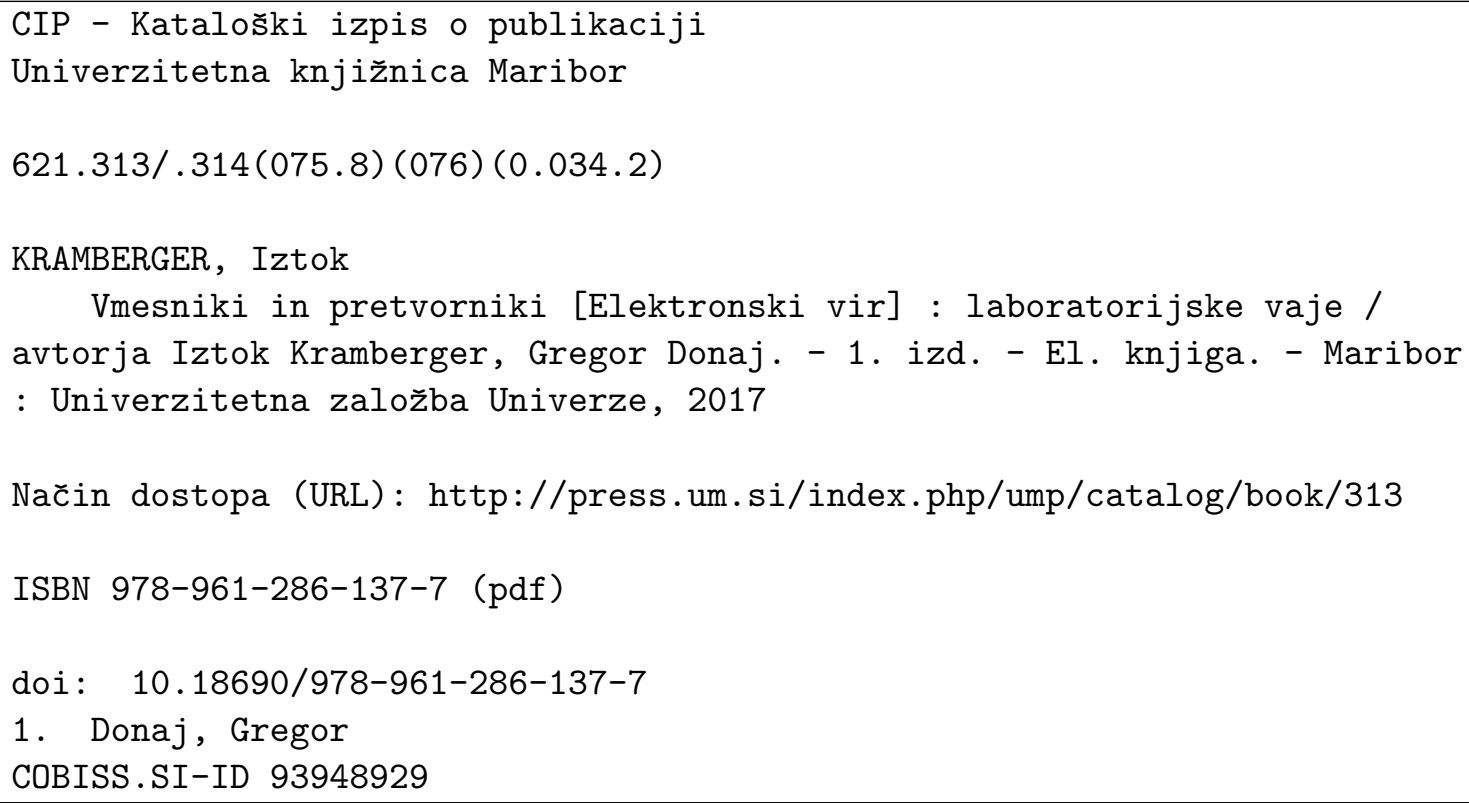

ISBN: $978-961-286-137-7$ (pdf)

DOI: https://doi.org/10.18690/978-961-286-137-7

Cena: Brezplačen izvod

Odgovorna oseba založnika: prof. dr. Žan Jan Oplotnik, prorektor univerze v Mariboru 

Vmesniki in pretvorniki: laboratorijske vaje

I. Kramberger in G. Donaj

\section{Vmesniki in pretvorniki: laboratorijske vaje Iztok Kramberger in Gregor Donaj}

Poveztek: Gradivo vsebuje navodila za laboratorijske vaje pri predmetu Vmesniki in pretvorniki za študente VS študijskega programa Elektrotehnika, smer elektronika. V navodilih je 12 laboratorijskih vaj, kjer se obravnavajo pretvorniki električnih veličin, merilni mostiči in ojačevalniki ter uporaba členov RC v pretvorbah. Drugi del vaj obravnava še neelektrične veličine in vezja za njihovo merjenje: optični pretvorniki, temperaturni senzor, senzor vlage, kapacitivni pretvornik, Hallova sonda in merilnik pretoka tekočine.

Ključne besede: elektronika, laboratorijske vaje, vmesniki, pretvornik, senzorji

NASLOVA AVTORJEV: dr. Iztok Kramberger, docent, Univerza v Mariboru, Fakulteta za elektrotehniko, računalništvo in informatiko, Koroška cesta 46, 2000 Maribor, Slovenija, e-naslov: iztok.kramberger@um.si. dr. Gregor Donaj, asistent z doktoratom, Univerza v Mariboru, Fakulteta za elektrotehniko, računalništvo in informatiko, Koroška cesta 46, 2000 Maribor, Slovenija, e-naslov: gregor.donaj@um.si. 



\section{Kazalo}

$\begin{array}{ll}\text { Uvod } & 1\end{array}$

Naloga 1: Tokovno-napetostni pretvornik 3

$\begin{array}{ll}\text { Naloga 2: Napetostno in tokovno napajan merilni mostič } & 7\end{array}$

$\begin{array}{ll}\text { Naloga 3: Detektor vršne napetosti } & 11\end{array}$

Naloga 4: Napetostno-frekvenčni pretvornik 15

$\begin{array}{ll}\text { Naloga 5: Frekvenčno-napetostni pretvornik } & 19\end{array}$

$\begin{array}{ll}\text { Naloga 6: Enosmerni pretvornik navzgor } & 23\end{array}$

$\begin{array}{ll}\text { Naloga 7: Preklopni časi optičnega povezovalnika } & 27\end{array}$

Naloga 8: Uporaba senzorjev in mikrokrmilnika 31

$\begin{array}{ll}\text { Naloga 9: Kapacitivni pretvorniki } & 35\end{array}$

$\begin{array}{ll}\text { Naloga 10: Pretok tekočine } & 37\end{array}$

Naloga 11: Gostota magnetnega pretoka 39

Naloga 12: Merjenje vpadne svetlobe $\quad 41$

$\begin{array}{ll}\text { Ocena } & 43\end{array}$ 



\section{Uvod}

V okviru laboratorijskih vaj pri predmetu Vmesniki in pretvorniki boste v praksi spoznali lastnosti in uporabo različnih elementov in vezij, ki se uporabljajo pri zajemanju in pretvorbi neelektričnih veličin v električne ter pretvorbi med električnimi veličinami. Laboratorijske vaje vsebujejo 12 nalog, ki so sicer samostojne, vendar v sklopih pokrivajo različne tematike - pretvorbe električnih veličin, uporabo RC členov, uporabo mikrokrmilnikov in senzorjev ter pretvorbe neelektričnih veličin.

V prvem delu vaj bomo spoznali pretvornike električnih veličin - diferenčni in instrumentacijski ojačevalnik ter tokovno in napetostno napajan merilni mostič. V prvi nalogi bomo uporabili diferenčni ojačevalnik za pretvorbo toka v napetost, $v$ drugi nalogi pa oba merilna mostiča in instrumentacijski ojačevalnik za merjenje temperature s temperaturno občutljivim elementom.

Za razne pretvorbe $\mathrm{v}$ zvezi s periodičnimi signali se uporabljajo kondenzatorji in upori za določanje časovnih konstant. V četrti nalogi boste tako spoznali primer načrtovanja RC člena v sledilniku vršne napetosti. Dve nadaljnji uporabi RC-členov sledita v nalogah 4 in 5 , kjer boste izvedli napetostno-frekvenčno in frekvenčno-napetostno pretvorbo.

Sledi naloga $\mathrm{z}$ enosmernim pretvornikom, kjer je ponazorjen vpliv bremena na pretvorbo, in naloga z merjenjem preklopnih časov optičnega povezovalnika, kjer so ponazorjene odvisnosti vezja in pretvorbe (v tem primeru prenos signala) glede na druge elemente v vezju.

$\mathrm{V}$ osmi nalogi bomo uporabili nekatere tipične senzorje temperature in vlage, ki se uporabljajo v elektroniki, ter ponazorili njihovo uporabo z mikrokrmilnikom. Podobno vezje je tudi uporabljeno v deveti nalogi, kjer pa bomo uporabili razvojno ploščo za preverjanje delovanja kapacitivno-napetostnega pretvornika.

V zadnjih treh nalogah bomo spoznali še nekatere elemente za pretvorbo neelektričnih veličin v električne. Te bodo dajalnik impulzov za merjenje pretoka tekočin, Hallova sonda za merjenje gostote magnetnega polja in fotoupor za merjenje vpadne svetlobe.

\section{Navodila za opravljanje laboratorijskih vaj}

Na laboratorijske vaje prihajajte pripravljeni, kar pomeni, da si pred začetkom vaj preberite nalogo. Pri reševanju nalog boste morali vpisovati odgovore na posamezna vprašanja in vpisovati merilne rezultate v tabele ter iz podatkov v tabelah risati grafe. Spodaj imate navedenih nekaj splošnih navodil za pravilno reševanje. Pri večini nalog sledi zadnji del z izračuni in dodatnimi vprašanji. Te izpolnjujte po končanem terminu laboratorijskih vaj.

\section{Tabele}

- Preden začnete zapisovati vrednosti, se prepričajte, ali vezje pravilno deluje in ali meritev opravljate pravilno.

- Bodite pozorni na enote $\mathrm{v}$ tabeli. Te so vpisane v prvi vrstici tabele.

- Podatke vpišite s primernim številom decimalnih mest. Zaokroževanje na premajhno število mest vnese dodatno napako, zaokroževanje na preveliko število mest pa je neprimerno, če je merska napaka bistveno večja od natančnosti vpisa vrednosti. 


\section{Grafi}

- Na obeh oseh zapišite veličine in merilo. Označite več enakomerno oddaljenih točk na oseh $\mathrm{z}$ vrednostmi.

- Uporabite vse izmerjene vrednosti iz ustrezne tabele in za vsako vrednost narišite dobro vidno točko na grafu.

- Graf lahko rišete prostoročno ali pa z ravnilom, kadar podatki nakazujejo dovolj linearen potek. V primeru (deloma) nelinearnega poteka ne rišite lomljenke med merilnimi točkami, ampak primerno narišite potek grafa med merilnimi točkami.

- Kadar imate na eni sliki več grafov, morajo biti vsi grafi nedvoumno označeni. 


\section{Naloga 1: Tokovno-napetostni pretvornik}

Navodilo naloge: Sestavite tokovno-napetostni pretvornik, ki deluje na osnovi diferenčnega ojačevalnika. S pomočjo meritev preverite njegovo delovanje ter izračunajte faktor pretvorbe.

\section{Uvod}

Tokovno-napetostni pretvornik realiziramo s pomočjo merilnega upora, na katerem merimo padec napetosti. Ker morda ne moremo zagotoviti, da bo eden izmed priključkov upora na potencialu $0 \mathrm{~V}$ (glede na merilni instrument), merimo napetost z diferenčnim ojačevalnikom, ki ga realiziramo z operacijskim ojačevalnikom in upori. Vezje diferenčnega ojačevalnika je prikazano na sliki 1 .

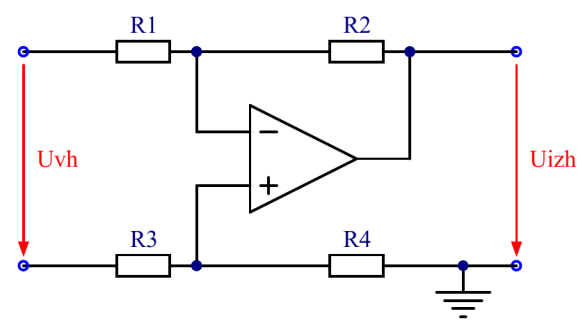

Slika 1: Diferenčni ojačevalnik

Za pravilno delovanje ojačevalnika, tj. ojačanje razlike napetosti med vhodnima priključkoma, mora veljati: $R_{1}=R_{3}$ in $R_{2}=R_{4}$. Izhodno napetost diferenčnega ojačevalnika potem izrazimo z enačbo:

$$
U_{i z h}=-U_{v h} \frac{R_{2}}{R_{1}} .
$$

Napetost $U_{v h}$ predstavlja razliko napetosti med obema vhodnima priključkoma. To napetost dobimo kot padec napetosti na vhodnem uporu, ki ga dodamo na vhod vezja. Padec napetosti na tem uporu je sorazmeren s tokom skozi njega:

$$
U_{v h}=I_{R_{v h}} \cdot R_{v h}
$$

Če obe enačbi združimo, dobimo enačbo za pretvorbo vhodnega toka v izhodno napetost:

$$
U_{i z h}=-\frac{R_{v h} \cdot R_{2}}{R_{1}} \cdot I_{R_{v h}} .
$$

Iz zadnje enačbe vidimo, da je izhodna napetost premo sorazmerna s tokom skozi merilni upor $R_{v h}$, faktor pretvorbe pa je $-\frac{R_{v h} \cdot R_{2}}{R_{1}}$. Če nadalje izberemo $R=R_{1}=R_{2}$, bo faktor pretvorbe enak $-R_{v h}$.

Sama izbira upora $R$ sicer ne vpliva na faktor pretvorbe med padcem napetosti na merilnem uporu in izhodno napetostjo, vendar pa moramo upoštevati, da vhodni tok ne bo enak toku skozi merilni upor. Del toka bo tekel v diferenčni ojačevalnik, katerega vhodna upornost ni neskončna, ampak je odvisna tudi od $R$. 


\section{Shema}

Na sliki 2 je prikazana vezalna shema pretvornika in merilnih instrumentov. Za operacijski ojačevalnik lahko uporabimo splošnonamenski ojačevalnik (npr. LM741, TL081 ali podoben), za upore $R$ vzamemo 4 enake upore. Ojačevalnik napajajmo z napetostjo $\pm 9 \mathrm{~V}$ (ni na shemi). Vhodni tok spreminjajmo s spreminjanjem napetosti na viru $V_{1}$.

$\mathrm{V}$ vezju naj bi bili vsi štirje upori v diferenčnem ojačevalniku enaki, vendar v praksi ti upori ne bodo nikoli popolnoma enaki. Da kljub temu dosežemo čim bolj natančno obnašanje vezja, izberemo upore z majhno toleranco (npr. 1\% ali manj).

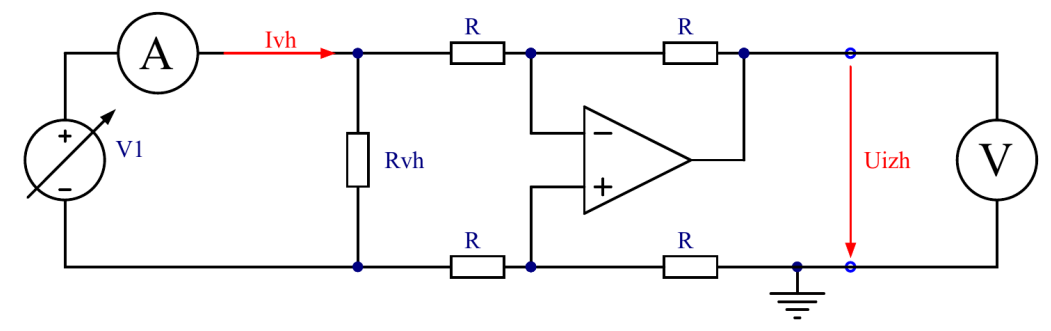

Slika 2: Vezalna shema tokovno-napetostnega pretvornika

\section{Potek vaje}

- Izberite ustrezen upor $R_{v h}$, tako da bo faktor pretvorbe $-1 \mathrm{~V} / \mathrm{mA}$.

- Z instrumentom izmerite točno vrednost upora $R_{v h}$, ki ga boste uporabili v vezju.

- Izberite $R=10 \mathrm{k} \Omega$.

- Sestavite vezje po zgornji shemi.

- Izmerite prenosno karakteristiko vezja v območju vhodnih tokov od $0 \mathrm{~mA}$ do $10 \mathrm{~mA} \mathrm{v}$ korakih po $1 \mathrm{~mA}$ ter narišite graf prenosne karakteristike.

- Ponovite meritev karakteristike za vrednost $R=100 \mathrm{k} \Omega$ ter narišite graf prenosne karakteristike na isto sliko.

- Opravite izračune in odgovorite na dodatna vprašanja. 


\section{Meritve in rezultati}

Koliko je zahtevana vrednost upora $R_{v h}$ ?

Odgovor:

Koliko je izmerjena vrednost izbranega upora $R_{v h}$ ?

Odgovor:

Tabela 1: Meritev prenosne karakteristike tokovno-napetostnega pretvornika

\begin{tabular}{|l|l|l|}
\hline$I_{v h}[\mathrm{~mA}]$ & $U_{i z h}(R=10 \mathrm{k} \Omega)[\mathrm{V}]$ & $U_{i z h}(R=100 \mathrm{k} \Omega)[\mathrm{V}]$ \\
\hline \hline & & \\
\hline & & \\
\hline & & \\
\hline & & \\
\hline & & \\
\hline & & \\
\hline & & \\
\hline & & \\
\hline & & \\
\hline
\end{tabular}

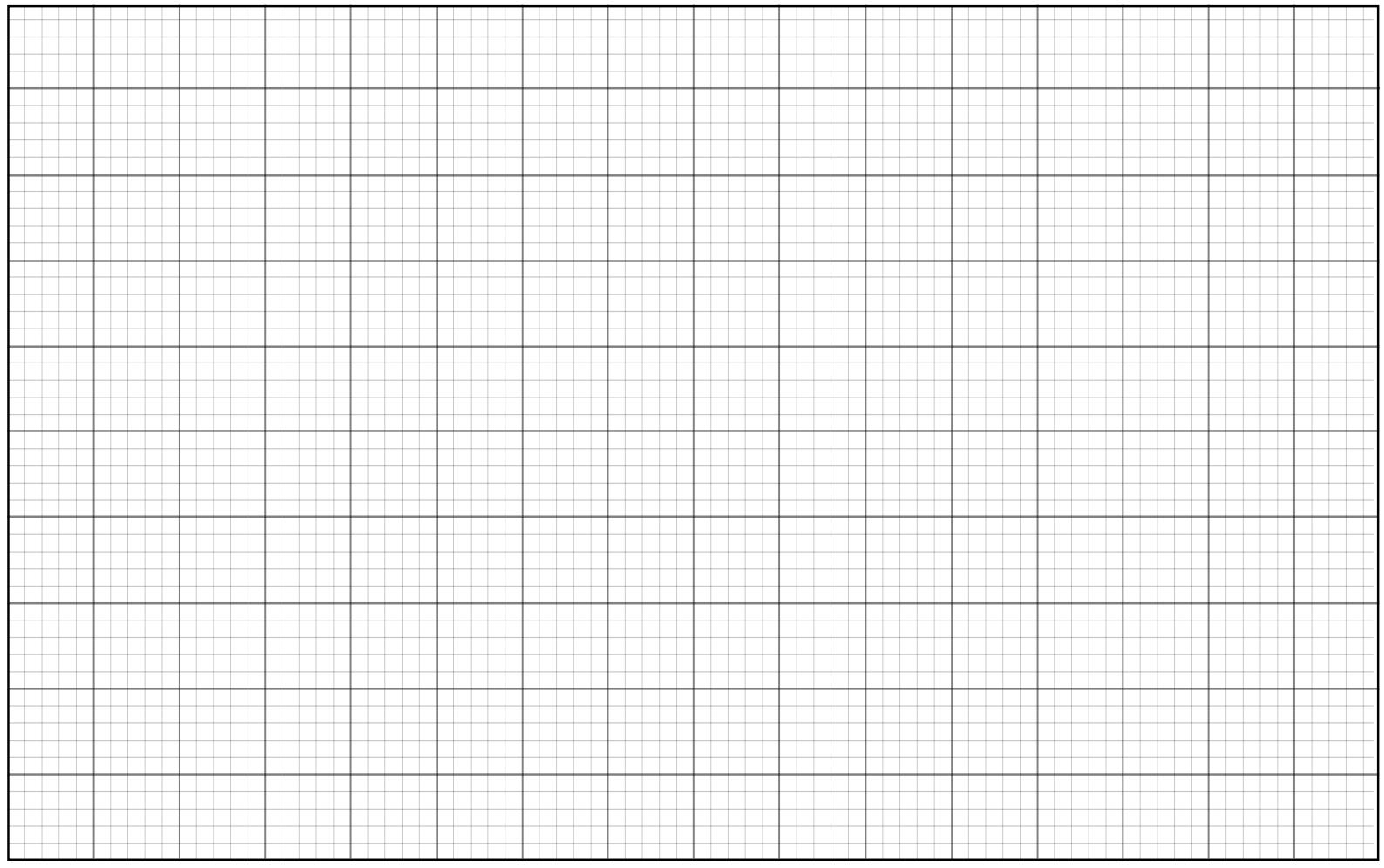

Slika 3: Prenosna karakteristika tokovno-napetostnega pretvornika 


\section{Izračuni in dodatna vprašanja}

- Izračunajte vhodno upornost vezja za obe izbiri upora $R$. Predpostavite, da bo nižji od obeh vhodnih potencialov na nivoju $0 \mathrm{~V}$. Kako bi se izračun razlikoval, če bi oba vhodna priključka bila plavajoča (nobeden ne bi bil vezan na potencial $0 \mathrm{~V}$ ).

- Iz meritev izračunajte faktor pretvorbe za obe izbiri upora $R$. 


\section{Naloga 2: Napetostno in tokovno napajan merilni mostič}

Navodilo naloge: Uporabite temperaturni pretvornik KTY 10-6, merilni mostič in instrumentacijski ojačevalnik za izvedbo vezja za merjenje temperature v območju od $0{ }^{\circ} \mathrm{C}$ do $100{ }^{\circ} \mathrm{C}$. Realizirajte dve vezji, kjer v prvem vezju uporabite napetostno napajan merilni mostič, v drugem vezju pa tokovno napajan merilni mostič.

\section{Uvod}

KTY 10-6 je temperaturni pretvornik, ki se mu glede na temperaturo spreminja upornost. V tej vaji imamo pretvornik vezan v merilni mostič. Uporabili bomo dva različna mostiča, ki sta prikazana na sliki 4 .

V prvi vezavi - napetostno napajan mostič - uporabimo konstantno napajalno napetost $1 \mathrm{~V}$ neposredno na merilnem mostiču. $\mathrm{V}$ drugi vezavi vežemo zaporedno z vezjem predupor $R_{p}$, katerega upornost mora biti bistveno večja od upornosti mostiča. Vezava napajalnega vira z višjo napetostjo in predupora se obnaša podobno kot tokovni vir z vzporedno vezanim uporom (Nortonov teorem). Ker je upornost mostiča bistveno manjša, bo njegov vpliv na tok v mostič ustrezno majhen. Na tak način realiziramo (skoraj) konstanten tok skozi mostič. Doseči želimo tok ca. $0,5 \mathrm{~mA}$.

Razliko napetosti v obeh vejah mostiča (na sliki označeno z $U_{v h}$ ) nato ojačamo do želene vrednosti z instrumentacijskim ojačevalnikom. Za razliko od diferenčnega ojačevalnika (glej vajo 1) ima instrumentacijski ojačevalnik zelo veliko vhodno upornost in posledično nima vpliva na tokovne in napetostne razmere $\mathrm{v}$ mostiču. Shema instrumentacijskega ojačevalnika je prikazana na sliki 5 .

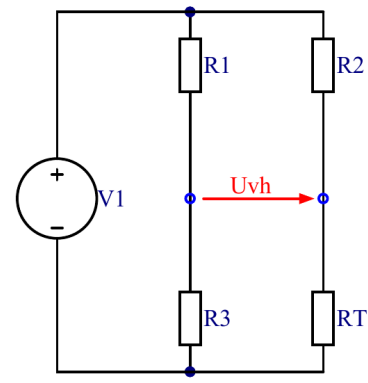

(a) Napetnostno napajan merilni mostič

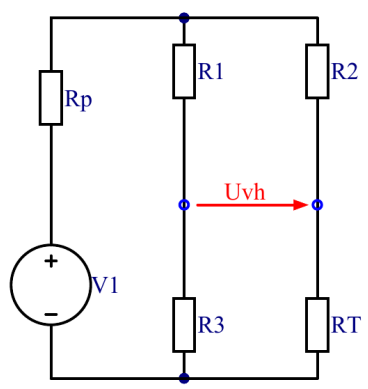

(b) Tokovno napajan merilni mostič

Slika 4: Merilna mostiča s fiksnimi upori $R_{1}, R_{2}$ in $R_{3}$ ter temperaturno odvisnim uporom $R_{T}$

Meritev temperature je zamudna, saj moramo najprej doseči stabilno želeno temperaturo pretvornika. Ker nas pri tej vaji zanima predvsem delovanje merilnega mostiča in pa instrumentacijskega ojačevalnika, lahko namesto temperaturnega pretvornika uporabimo uporovno dekado, s katero emuliramo pretvornik pri različnih temperaturah. Odvisnost njegove upornosti od temperature je podana $\mathrm{v}$ tabeli 2 . 


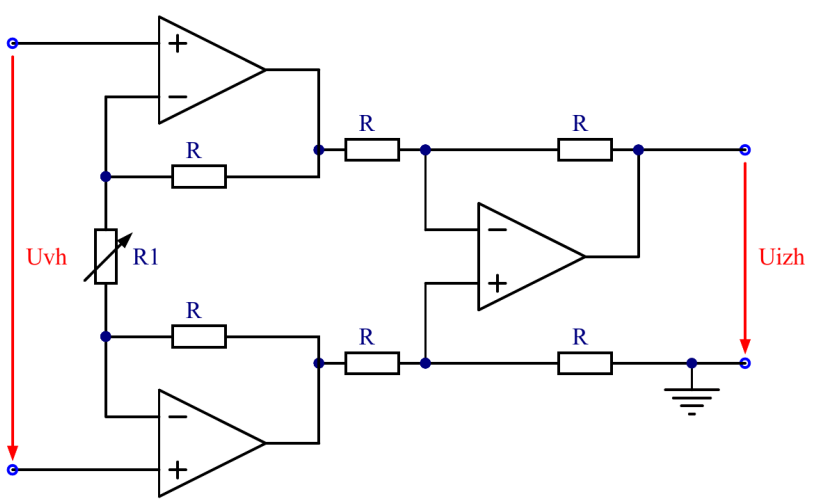

Slika 5: Instrumentacijski ojačevalnik, ki mu lahko ojačanje nastavljamo z uporom $R_{1}$

Tabela 2: Upornost pretvornika KTY 10-6 pri različnih temperaturah

\begin{tabular}{|c|c||c|c||c|c||c|c|}
\hline $\mathrm{T}\left[{ }^{\circ} \mathrm{C}\right]$ & $R_{T}[\Omega]$ & $\mathrm{T}\left[{ }^{\circ} \mathrm{C}\right]$ & $R_{T}[\Omega]$ & $\mathrm{T}\left[{ }^{\circ} \mathrm{C}\right]$ & $R_{T}[\Omega]$ & $\mathrm{T}\left[{ }^{\circ} \mathrm{C}\right]$ & $R_{T}[\Omega]$ \\
\hline \hline 0 & 1630 & 30 & 2080 & 60 & 2599 & 90 & 3188 \\
5 & 1700 & 35 & 2161 & 65 & 2692 & 95 & 3293 \\
10 & 1772 & 40 & 2245 & 70 & 2788 & 100 & 3400 \\
15 & 1846 & 45 & 2331 & 75 & 2885 & & \\
20 & 1922 & 50 & 2418 & 80 & 2984 & & \\
25 & 2000 & 55 & 2508 & 85 & 3085 & & \\
\hline
\end{tabular}

\section{Shema}

Za opravljanje naloge imate pripravljeno tiskano vezje. Na njem je merilni mostič s tremi upori in spremenljivim uporom $P_{2}$, ki ga uporabimo za umerjanje mostiča. Uporovno dekado, s katero emuliramo temperaturni pretvornik, priklopimo med priključka TEMP + in TEMP -. Razliko napetosti v mostiču ojačamo z instrumentacijskim ojačevalnikom, da dobimo izhodno napetost $U_{i z h}$. Vezje napajamo z napetostjo $\pm 15 \mathrm{~V}$.

$\mathrm{V}$ mostiču imata zgornja upora (na sliki 4 upora $R_{1}$ in $R_{2}$ ) upornost $2,2 \mathrm{k} \Omega$, upor $R_{3}$ pa je v vezju sestavljen iz fiksnega in spremenljivega upora. Med izvajanjem vaje bomo z $R_{3}$ umerili mostič na izhod $U_{i z h}=0 \mathrm{~V}$ pri $0{ }^{\circ} \mathrm{C}$. Velja še: $R_{p}=27 \mathrm{k} \Omega$.

\section{Potek vaje}

- Pripravite vezje in priključite napajalni vir.

- Pri temperaturi $0{ }^{\circ} \mathrm{C}$ nastavite upor $P_{2}$ tako, da bo izhodna napetost $0 \mathrm{~V}$. Pri temperaturi $100{ }^{\circ} \mathrm{C}$ nastavite upor $P_{1}$ tako, da bo izhodna napetost $10 \mathrm{~V}$.

- Izmerite prenosno karakteristiko pretvornika v območju od $0{ }^{\circ} \mathrm{C}$ do $100{ }^{\circ} \mathrm{C}$ v korakih po 5 ${ }^{\circ} \mathrm{C}$ za oba mostiča ter narišite obe prenosni karakteristiki.

- Opravite izračune in odgovorite na dodatna vprašanja. 


\section{Meritve in rezultati}

Za pravilno delovanje bo treba umeriti mostič (spremenljiv upor $P_{2}$ ), da dobimo pravilno točko ravnovesja. S tem dosežemo pri želeni temperaturi $0{ }^{\circ} \mathrm{C}$ izhodno napetost $0 \mathrm{~V}$. Razliko napetosti v obeh vejah mostiča nato ojačamo z instrumentacijskim ojačevalnikom. Temu še moramo nastaviti ojačanje (spremenljiv upor $P_{1}$ ), da dobimo želeni faktor pretvorbe.

$\mathrm{V}$ napetostnem merilnem mostiču uporabite napajalno napetost $1 \mathrm{~V}$ ter kratko sklenite predupor mostiča. $\mathrm{V}$ tokovnem mostiču pa uporabite napajalno napetost $+15 \mathrm{~V}$ in upor $R=27 \mathrm{k} \Omega$.

Tabela 3: Meritev prenosne karakteristike temperaturno-napetostnega pretvornika

\begin{tabular}{|c|c||c|c||c|c|c|c|}
\hline \multicolumn{4}{|c||}{ Napetostno napajan mostič } & \multicolumn{5}{c|}{ Tokovno napajan mostič } \\
\hline $\mathrm{T}\left[{ }^{\circ} \mathrm{C}\right]$ & $U_{\text {out }}[\mathrm{V}]$ & $\mathrm{T}\left[{ }^{\circ} \mathrm{C}\right]$ & $U_{\text {out }}[\mathrm{V}]$ & $\mathrm{T}\left[{ }^{\circ} \mathrm{C}\right]$ & $U_{\text {out }}[\mathrm{V}]$ & $\mathrm{T}\left[{ }^{\circ} \mathrm{C}\right]$ & $U_{\text {out }}[\mathrm{V}]$ \\
\hline \hline 0 & & 55 & & 0 & & 55 & \\
\hline 5 & & 60 & & 5 & & 60 & \\
\hline 10 & & 65 & & 10 & & 65 & \\
\hline 15 & & 70 & & 15 & & 70 & \\
\hline 20 & & 75 & & 20 & & 75 & \\
\hline 25 & & 80 & & 25 & & 80 & \\
\hline 30 & & 85 & & 30 & & 85 & \\
\hline 35 & & 90 & & 35 & & 90 & \\
\hline 40 & & 95 & & 40 & & 95 & \\
\hline 45 & & 100 & & 45 & & 100 & \\
\hline 50 & & & & 50 & & & \\
\hline
\end{tabular}

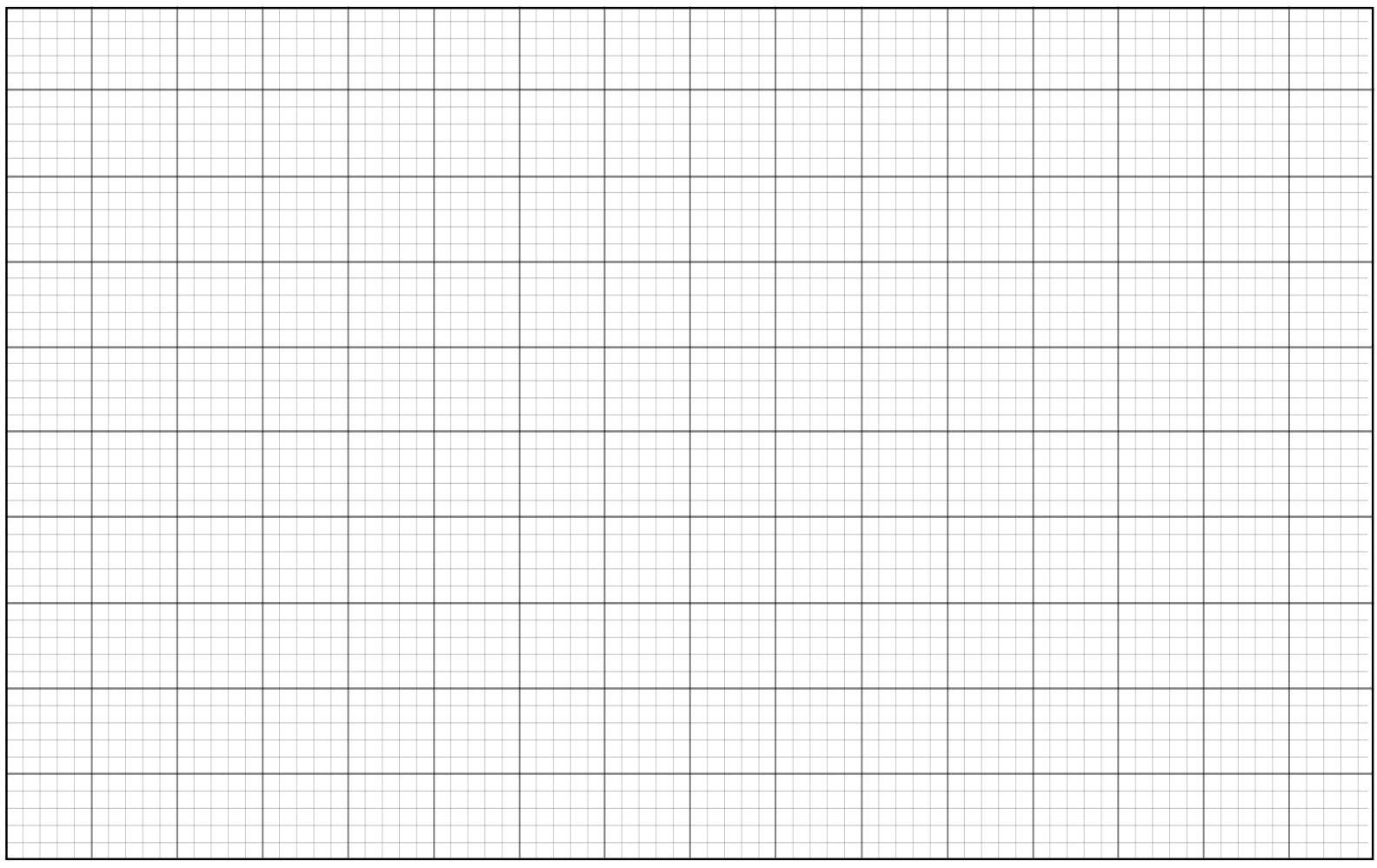

Slika 6: Prenosna karakteristika temperaturno-napetostnega pretvornika 


\section{Izračuni in dodatna vprašanja}

- Izračunajte največjo nelinearnost v obeh prenosnih karakteristikah.

- Izračunajte največji in najmanjši tok skozi merilni mostič v obeh različicah mostiča. Upoštevajte napajalno napetost in vrednosti za $R_{T}$ ter predupor $R_{p}=27 \mathrm{k} \Omega$. 


\section{Naloga 3: Detektor vršne napetosti}

Navodilo naloge: Sestavite vezje za zaznavanje vršne napetosti (angl. peak detector) v sinusnem signalu. Pri tem načrtujte RC-člen znotraj detektorja za primerno delovanje pri frekvenci $1 \mathrm{kHz}$. Z meritvami določite njegovo delovanje pri sinusnih vhodnih signalih različnih amplitud in frekvenc.

\section{Uvod}

Detektor vršne napetosti najenostavneje sestavimo kot polvalni usmernik z vzporedno vezavo kondenzatorja in upora na izhodni strani, kot je prikazano na sliki 7 .

Kadar je napetost na vhodu vezja od napetosti na kondenzatorju višja vsaj za kolensko napetost diode, bo v vezje tekel tok in napetost na kondenzatorju se bo povečevala. Kadar pa bo napetost na vhodu manjša od napetosti na kondenzatorju, bo napetost na kondenzatorju počasi padala, saj se bo ta praznil čez upor $R$. Izhodna napetost bo tako sledila vrhom v vhodni napetosti, zmanjšanim za kolensko napetost diode. Takšno vezje pa bo delovalo le, če bo frekvenca vhodnega signala v primernem območju.

Razen zmanjšanja izhodne napetosti ima to vezje še slabost, da ima majhno vhodno upornost. Obe slabosti odpravimo z uporabo vezja na sliki 8 , ki ga boste pri tej vaji sestavili. To vezje deluje na podobnem principu kot prvo vezje. Vhodni tok operacijskega ojačevalnika je zanemarljivo majhen. S tem je tudi padec napetosti na uporu $R_{1}$ zanemarljivo majhen. Kot vemo, operacijski ojačevalnik deluje tako, da bo dvigoval napetost na izhodu, dokler ne bo napetost na invertirajočem vhodu dosegla napetosti na neinvertirajočem. Tako bo napetost na izhodu dosegla napetost na vhodu kljub padcu napetosti na diodi.

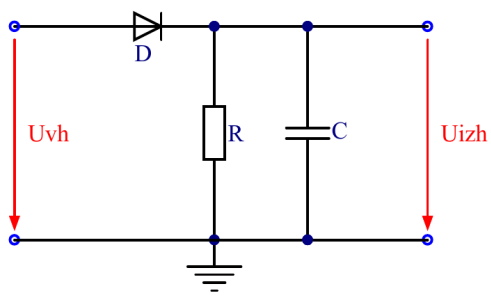

Slika 7: Preprosto vezje detektorja vršne napetosti 


\section{Shema}

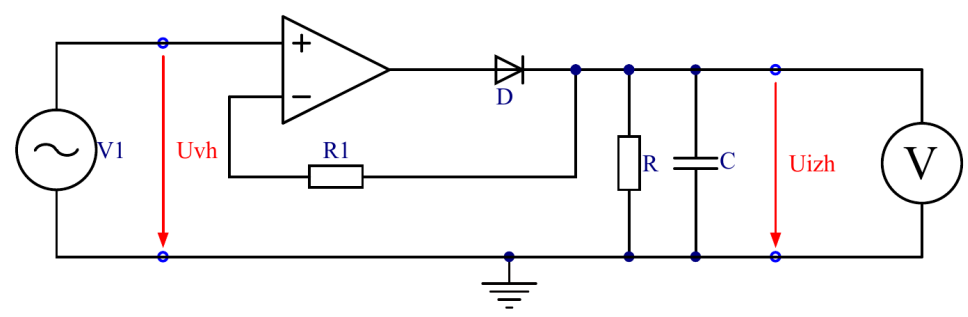

Slika 8: Vezalna shema za izvedbo detektorja vršne napetosti

Za operacijski ojačevalnik v shemi lahko uporabimo splošnonamenski ojačevalnik (npr. LM741, TL081 ...). Napajajmo ga z napetostjo $\pm 9 \mathrm{~V}$. Izbira upora $R_{1}$ ni bistvena za delovanje vezja. Izberimo na primer $10 \mathrm{k} \Omega$. Za diodo izberimo hitro preklopno diodo (npr. 1N4148). Potek izhodne napetosti bo odvisen od izbire upora $R$ in kondenzatorja $C$; natančneje, potek bo odvisen od časovne konstante $\tau=R \cdot C$. Načrtujte vezje tako, da bo pri vhodnem signalu frekvence $1 \mathrm{kHz}$ izhodni signal med vrhoma padel za $5 \%$ vršne napetosti.

\section{Potek vaje}

- Izberite par upora $R$ in kondenzatorja $C$. Na shemi zabeležite vrednosti. Izberite elementa, tako da bo pri frekvenci $1 \mathrm{kHz}$ napetost med zaporednima vrhoma na kondenzatorju padla za približno $5 \%$.

- Sestavite vezje in priključite napajanje ter voltmeter. Za preverjanje pravilnega delovanja priključite še osciloskop in opazujte tako vhodni kot izhodni signal. Nastavite frekvenco vhodne napetosti $1 \mathrm{kHz}$ in spreminjajte amplitudo od $0 \mathrm{~V}$ do $10 \mathrm{~V}$ v korakih po $1 \mathrm{~V}$. $\mathrm{Na}$ izhodu merite povprečno napetost (uporabimo voltmeter v načinu merjenja enosmerne napetosti).

- Izmerite valovitost od vrha do vrha (peak-to-peak) izhodne napetosti pri vhodnem signalu z amplitudo $5 \mathrm{~V}$ pri frekvencah $10 \mathrm{~Hz}, 20 \mathrm{~Hz}, 50 \mathrm{~Hz}, 100 \mathrm{~Hz}, 200 \mathrm{~Hz}, 500 \mathrm{~Hz}, 1 \mathrm{kHz}, 2$ $\mathrm{kHz}, 5 \mathrm{kHz}, 10 \mathrm{kHz}, 20 \mathrm{kHz}$ in $50 \mathrm{kHz}$.

- Izmerite, koliko časa potrebuje izhodni signal, da ponovno doseže vrednost vhodnega signala, če le-ta spremeni amplitudo s $5 \mathrm{~V}$ na $2,5 \mathrm{~V}$-izmerite dolžino prehodnega pojava.

- Narišite graf prenosne karakteristike med vhodno napetostjo in povprečno izhodno napetostjo.

- Opravite izračune in odgovorite na dodatna vprašanja.

Izračun $R$ in $C$ : 


\section{Meritve in rezultati}

Tabela 4: Meritve povprečne vrednosti izhodne napetosti detektorja vršne napetosti $(f=1 \mathrm{kHz})$

\begin{tabular}{|l|l||l|l|}
\hline$U_{v h}[\mathrm{~V}]$ (ampl.) & $U_{i z h}[\mathrm{~V}]$ (povp.) & $U_{v h}[\mathrm{~V}](\mathrm{ampl})$ & $U_{i z h}[\mathrm{~V}]$ (povp.) \\
\hline \hline & & & \\
\hline & & & \\
\hline & & & \\
\hline & & & \\
\hline & & & \\
\hline
\end{tabular}

Tabela 5: Meritve valovitosti izhodne napetosti detektorja vršne napetosti $\left(U_{v h}=10 \mathrm{~V}_{\mathrm{pp}}\right)$

\begin{tabular}{|c|c||c|c|}
\hline$f[\mathrm{~Hz}]$ & $U_{i z h}[\mathrm{~V}](\mathrm{pp})$ & $f[\mathrm{~Hz}]$ & $U_{i z h}[\mathrm{~V}](\mathrm{pp})$ \\
\hline \hline & & & \\
\hline & & & \\
\hline & & & \\
\hline & & & \\
\hline & & & \\
\hline
\end{tabular}

Koliko časa traja prehodni pojav pri spremembi amplitude?

Odgovor:

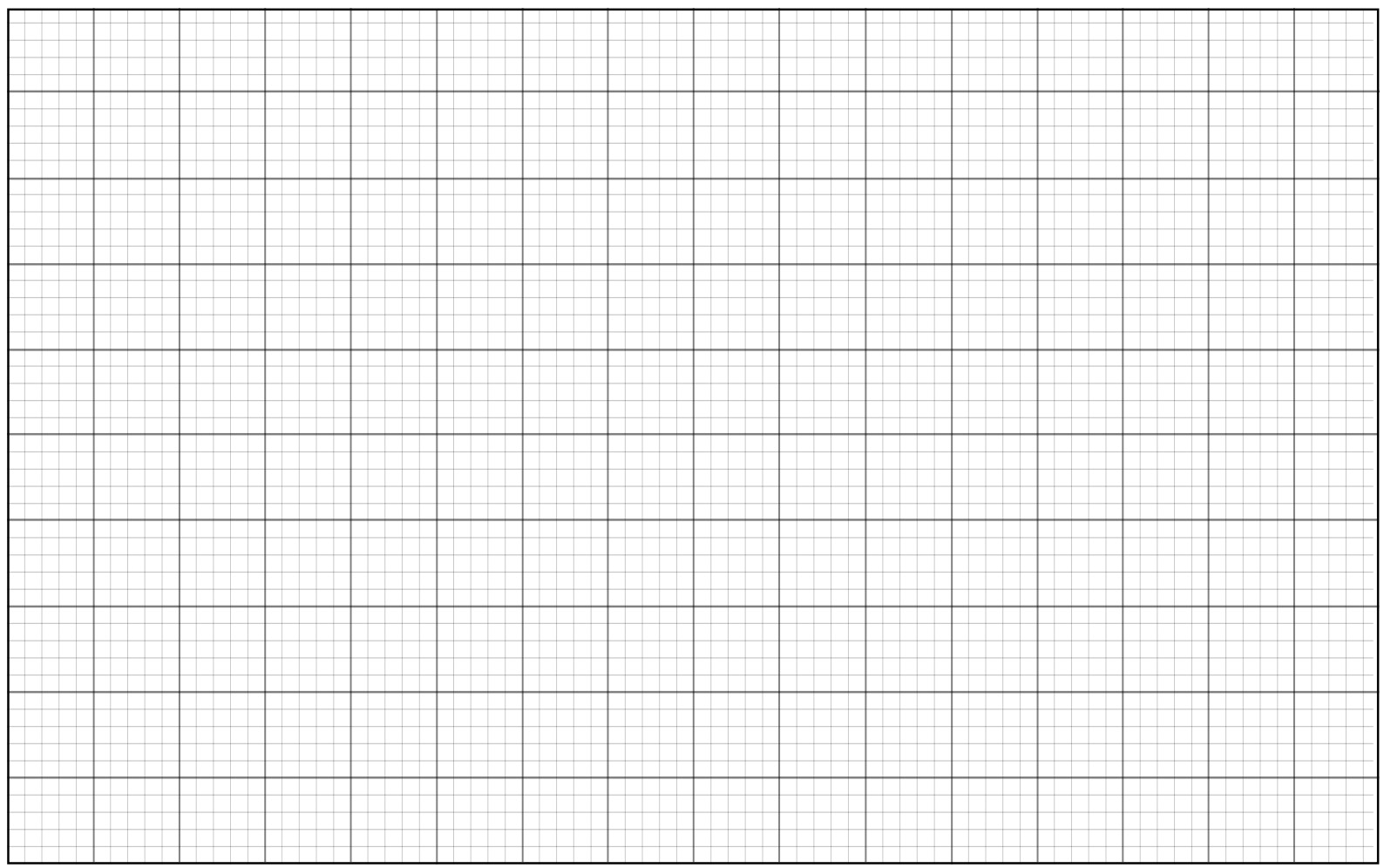

Slika 9: Prenosna karakteristika detektorja vršne napetosti 


\section{Izračuni in dodatna vprašanja}

- Pojasnite obliko izhodnega signala pri najnižji in najvišji frekvenci vhodnega signala v meritvah.

- Pojasnite prednosti in slabosti izbire večje časovne konstante $\tau=R C$ za signal neke frekvence in spremenljive amplitude. 


\section{Naloga 4: Napetostno-frekvenčni pretvornik}

Navodilo naloge: Sestavite napetostno-frekvenčni pretvornik in pri tem uporabite integrirano vezje LM331. Pretvornik naj na svojem izhodu tvori signal s frekvenco, ki bo linearno odvisna od napetosti vhodnega signala. Vezje načrtujte tako, da bo faktor pretvorbe $1 \mathrm{kHz} / \mathrm{V}$.

\section{Uvod}

Integrirano vezje LM331 je natančen napetostno-frekvenčni in frekvenčno-napetostni pretvornik, ki ponuja do 0,01\% nelinearnosti pretvorbe. $\mathrm{V}$ tej nalogi ga bomo uporabili kot napetostno frekvenčni pretvornik, tako da bomo sestavili vezje na sliki 10. Doseči hočemo faktor pretvorbe $1 \mathrm{kHz} / \mathrm{V}$. Da bomo to dosegli, moramo naprej določiti vrednosti nekaterih elementov v vezju.

RC vezje $R_{0} C_{0}$, ki je priključeno na priključek 5 integriranega vezja LM331, določa faktor pretvorbe. Frekvenca signala na izhodnem priključku 3 je sorazmerna z napetostjo na vhodu (priključek 7). Izhod je tipa Open-Collector, kar omogoča prilagoditev izhodne napetosti na poljubne nivoje z uporabo dvižnega (pull-up) upora.

Odvisnost frekvence izhodnega signala od vhodne napetosti $U_{v h}$ je podana ${ }^{1}$ z izrazom:

$$
f_{0}=k \cdot U_{v h},
$$

kjer se faktor pretvorbe $k$ izračuna na podlagi parametrov vezja z izrazom:

$$
k=0,48 \cdot \frac{R_{S}}{R_{B} \cdot R_{0} \cdot C_{0}} .
$$

Notranje delovanje vezja temelji na preciznem tokovnem viru, ki s tokovnimi pulzi iz priključka 1 uravnava napetost na kondenzatorju $C_{B}$ in s tem na priključku 6 . Tokovne impulze proži primerjalnik, ki primerja vhodne napetosti na priključkih 6 in 7 . Velikost toka pa nadzorujemo z upornostjo $R_{S}$ na priključku 2 . Ta naj bo $14 \mathrm{k} \Omega$.

\footnotetext{
${ }^{1}$ Enačbe za obnašanje vezja so podane v tehničnem dokumentu vezja
} 


\section{Shema}

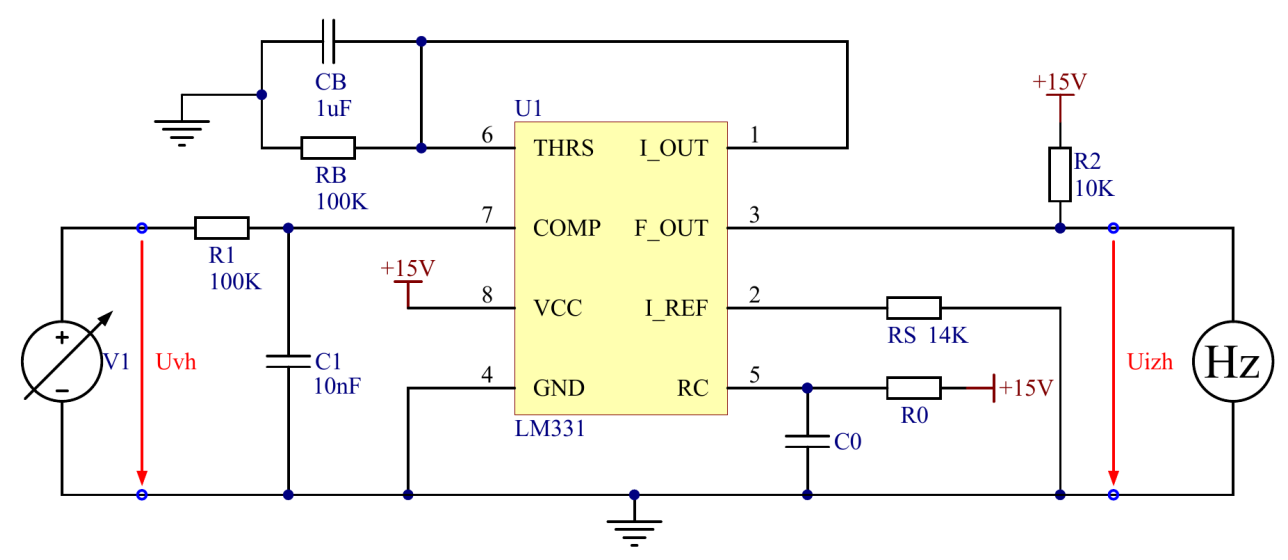

Slika 10: Vezje za napetostno-frekvenčno pretvorbo

Upor $R_{0}$ in kondenzator $C_{0}$ je potrebno izračunati. Upor $R_{2}$ je dvižni (pull-up) upor, ki izhod dvigne na napetost, ki je nanj priključena. Vhodno napetost lahko tvorimo s funkcijskim generatorjem ali napajalnikom, frekvenco izhodnega signala pa lahko merimo z osciloskopom ali pa frekvencmetrom.

\section{Potek vaje}

- Izračunajte manjkajoče vrednosti elementov $\left(R_{0}\right.$ in $\left.C_{0}\right)$.

- Sestavite vezje in priključite napajanje.

- Na vhod priključite enosmerno napetost, izhod pa opazujte z osciloskopom.

- Vhodno napetost spreminjajte od $0 \mathrm{~V}$ do $15 \mathrm{~V}$ v korakih po $0,5 \mathrm{~V}$ in merite frekvenco izhodnega signala.

- Določite tudi največjo vhodno napetost, pri kateri vezje še pravilno deluje.

- Narišite graf prenosne karakteristike.

- Opravite izračune in odgovorite na dodatna vprašanja.

Izračun $R_{0}$ in $C_{0}$ : 


\section{Meritve in rezultati}

Tabela 6: Meritve prenosne karakteristike napetostno-frekvenčnega pretvornika

\begin{tabular}{|l|l||l|l|}
\hline$U_{v h}[\mathrm{~V}]$ & $f_{0}[\mathrm{kHz}]$ & $U_{v h}[\mathrm{~V}]$ & $f_{0}[\mathrm{kHz}]$ \\
\hline \hline & & & \\
\hline & & & \\
\hline & & & \\
\hline & & & \\
\hline & & & \\
\hline & & & \\
\hline & & & \\
\hline & & & \\
\hline & & & \\
\hline & & & \\
\hline & & & \\
\hline
\end{tabular}

Koliko je največja vhodna napetost, pri kateri pretvornik še pravilno deluje?

Odgovor:

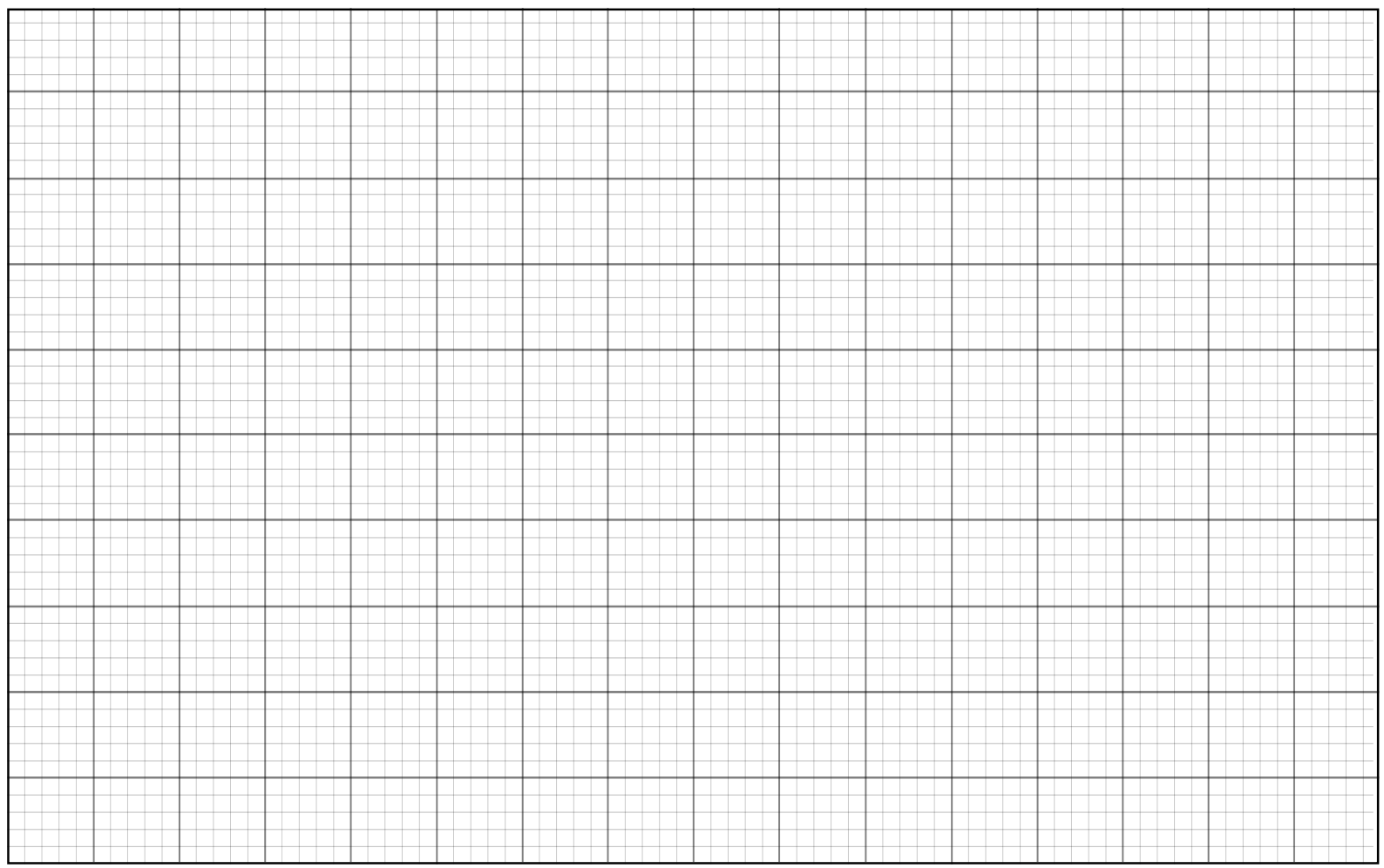

Slika 11: Prenosna karakteristika napetostno-frekvenčnega pretvornika 


\section{Izračuni in dodatna vprašanja}

- Izračunajte faktor pretvorbe in nelinearnost.

- Koliko je območje delovanja pretvornika? 


\section{Naloga 5: Frekvenčno-napetostni pretvornik}

Navodilo naloge: Sestavite frekvenčno-napetostni pretvornik in pri tem uporabite integrirano vezje LM331. Pretvornik naj na svojem izhodu tvori napetost, ki bo linearno odvisna od frekvence vhodnega signala. Vezje načrtujte tako, da bo faktor pretvorbe $1 \mathrm{~V} / \mathrm{kHz}$.

Integrirano vezje LM331 je natančen napetostno-frekvenčni in frekvenčno-napetostni pretvornik, ki ponuja do 0,01\% nelinearnosti pretvorbe. $\mathrm{V}$ tej nalogi ga bomo uporabili kot napetostno frekvenčni pretvornik, tako da bomo sestavili vezje na sliki 12. Doseči hočemo faktor pretvorbe $1 \mathrm{kHz} / \mathrm{V}$. Da bomo to dosegli, moramo naprej določiti vrednosti nekaterih elementov v vezju.

RC vezje $R_{0} C_{0}$, ki je priključeno na priključek 5 integriranega vezja LM331, določa faktor pretvorbe. Tokovni izhod na priključku 1 je proporcionalen frekvenci signala na priključku 6 .

Odvisnost izhodne napetosti $U_{i z h}$ od frekvence vhodnega signala $f_{v h}$ je podana z izrazom:

$$
U_{i z h}=k \cdot f_{v h}
$$

kjer se konstanta $k$ izračuna na podlagi parametrov vezja z izrazom:

$$
k=2,08 \cdot \frac{R_{B} \cdot R_{0} \cdot C_{0}}{R_{S}} .
$$

Notranje delovanje vezja temelji na preciznem tokovnem viru, ki s tokovnimi pulzi iz priključka 1 uravnava napetost na paru $C_{B}, R_{B}$. Tokovne impulze proži primerjalnik, ki primerja vhodni signal na priključku 6 s konstantno napetostjo na priključku 7, velikost toka pa nadzorujemo z upornostjo $R_{S}$ na priključku 2 . Ta naj bo $14 \mathrm{k} \Omega$. Velikost izhodne napetosti določa $R_{B}$, na katerem se pojavi padec napetosti, ki je sorazmeren s povprečno vrednostjo toka. 


\section{Shema}

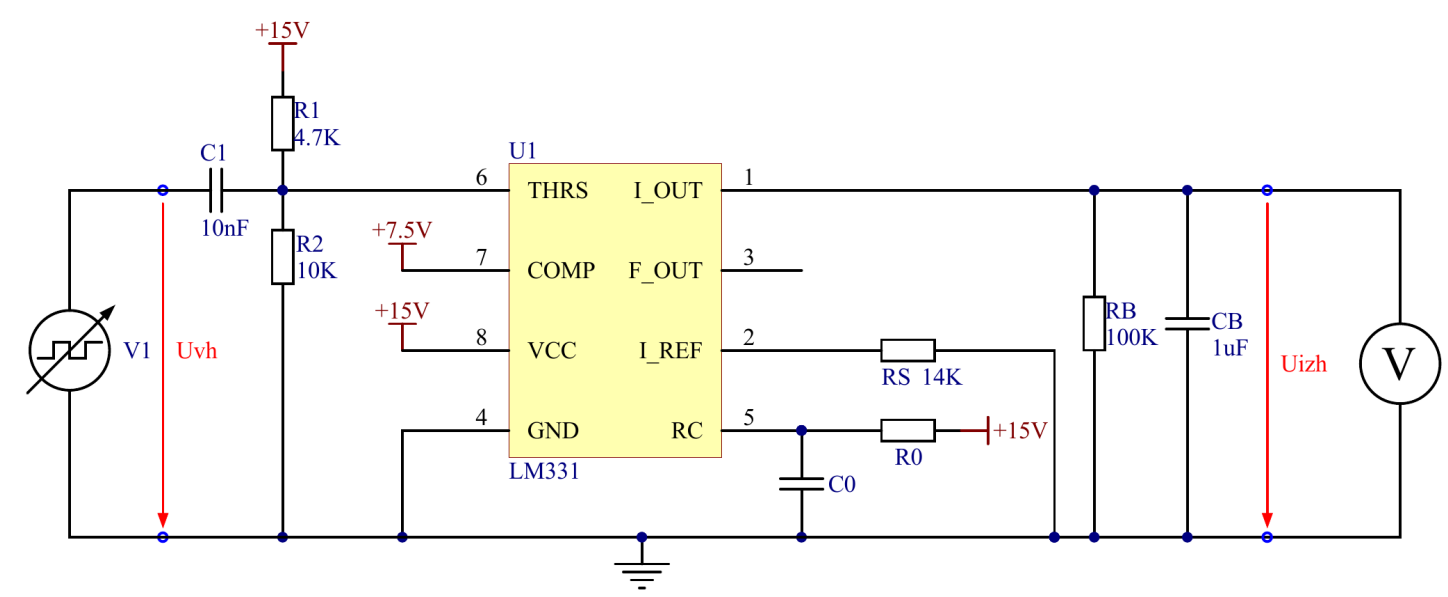

Slika 12: Vezje za frekvenčno-napetostno pretvorbo

Upor $R_{0}$ in kondenzator $C_{0}$ je potrebno izračunati. Upora $R_{1}$ in $R_{2}$ ter kondenzator $C_{1}$ delujejo kot visokoprepustni filter, s katerim odstranimo enosmerno komponento iz vhodnega signala ter dodamo novo enosmerno komponento velikosti ca. $10 \mathrm{~V}$.

Vhodni signal, ki ga tvorite s funkcijskim generatorjem, naj ima amplitudo $5 \mathrm{~V}_{\mathrm{pp}}$. Frekvenco lahko kar odčitate na funkcijskem generatorju, za meritev izhodne napetosti pa uporabite voltmeter.

\section{Potek vaje}

- Izračunajte manjkajoče vrednosti elementov $\left(R_{0}\right.$ in $\left.C_{0}\right)$.

- Sestavite vezje in priključite napajanje.

- Na vhod priključite pravokotni signal z amplitudo $5 \mathrm{~V}_{\mathrm{pp}}$.

- Frekvenco vhodnega signala spreminjajte od 0 do $15 \mathrm{kHz}$ v korakih po $0,5 \mathrm{kHz}$ in merite napetost izhodnega signala.

- Določite tudi najvišjo frekvenco vhodnega signala, pri kateri vezje še pravilno deluje.

- Narišite graf prenosne karakteristike.

- Opravite izračune in odgovorite na dodatna vprašanja.

Izračun $R_{0}$ in $C_{0}$ : 


\section{Meritve in rezultati}

Tabela 7: Meritve prenosne karakteristike frekvenčno-napetostnega pretvornika

\begin{tabular}{|l|l||l|l|}
\hline$f_{0}[\mathrm{kHz}]$ & $U_{i z h}[\mathrm{~V}]$ & $f_{0}[\mathrm{kHz}]$ & $U_{i z h}[\mathrm{~V}]$ \\
\hline \hline & & & \\
\hline & & & \\
\hline & & & \\
\hline & & & \\
\hline & & & \\
\hline & & & \\
\hline & & & \\
\hline & & & \\
\hline & & & \\
\hline & & & \\
\hline & & & \\
\hline
\end{tabular}

Koliko je največja frekvenca vhodnega signala, pri kateri vezje še pravilno deluje?

\section{Odgovor:}

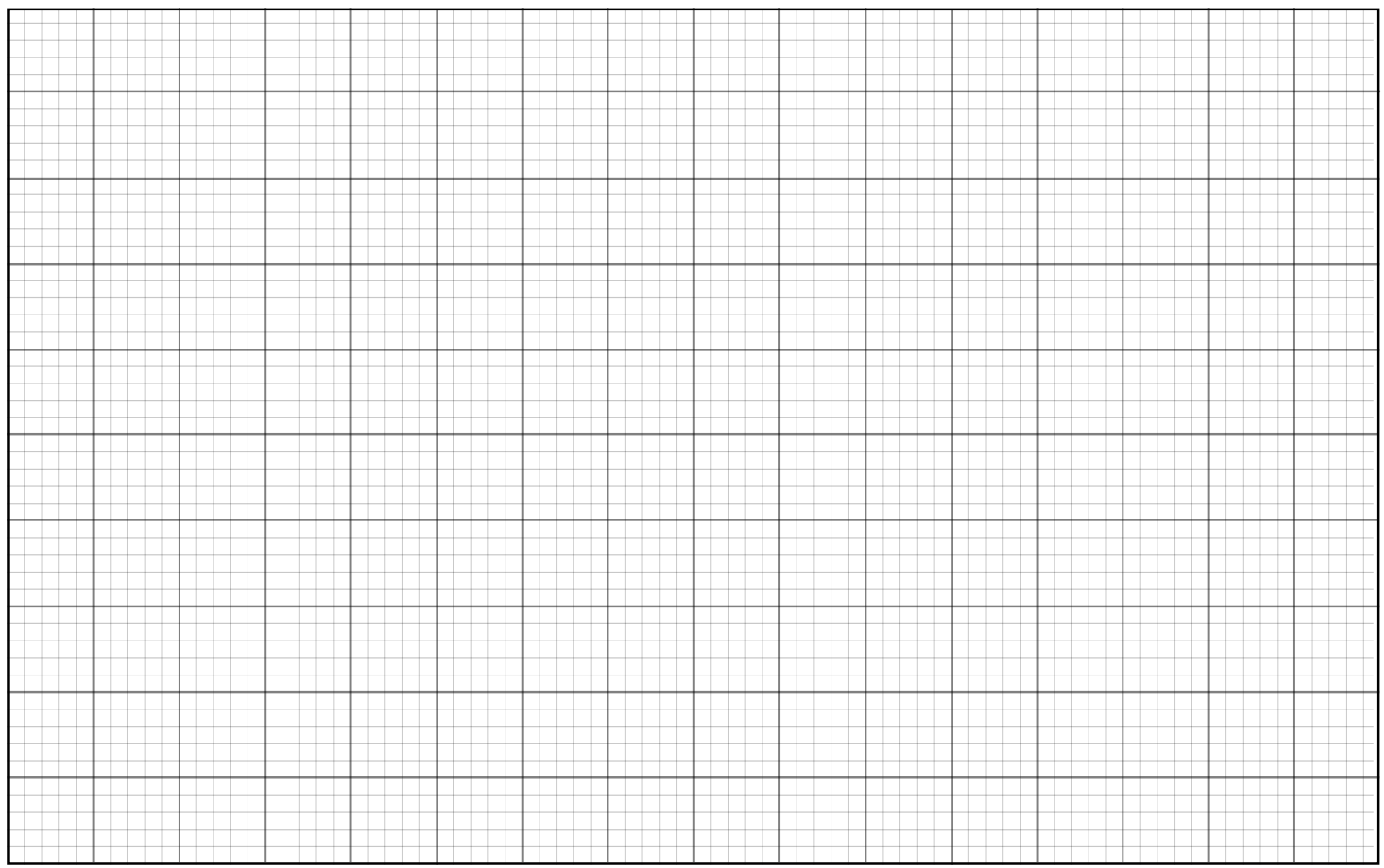

Slika 13: Prenosna karakteristika frekvenčno-napetostnega pretvornika 


\section{Izračuni in dodatna vprašanja}

- Izračunajte faktor pretvorbe in nelinearnost.

- Koliko je območje delovanja pretvornika? 


\section{Naloga 6: Enosmerni pretvornik navzgor}

Navodilo naloge: Sestavite vezje, ki bo vsebovalo enosmerni pretvornik navzgor (angl. Boost Converter), in pomerite njegove karakteristike: faktor pretvorbe in odvisnost izhodnega toka od bremena.

\section{Uvod}

Enosmerni pretvornik Murata MEE1S0509 je DC-DC pretvornik, ki omogoča pretvorbo navzgor s $5 \mathrm{~V}$ na $9 \mathrm{~V}$ ter galvansko ločitev vhodnega in izhodnega dela. Dovoljeno območje vhodne napetosti je od 4,5 $\mathrm{V}$ do $5,5 \mathrm{~V}$, dovoljena moč pa je $1 \mathrm{~W}$.

\section{Shema}

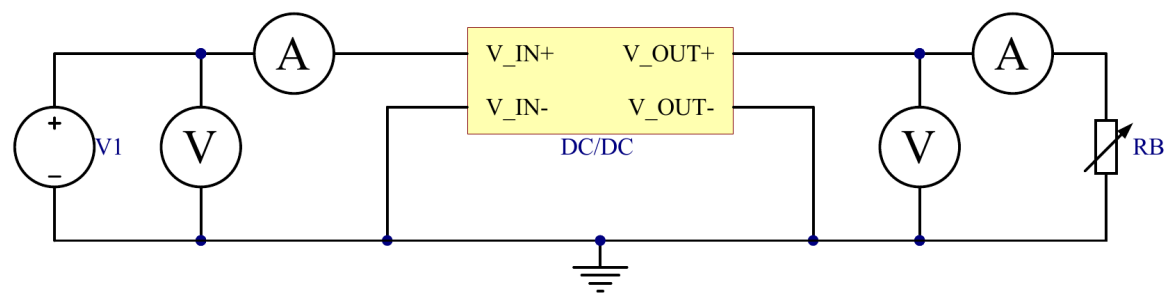

Slika 14: DC/DC pretvornik navzgor

Za vhodni napetostni vir uporabite laboratorijski napajalnik z dovolj velikim izhodnim tokom. Za breme $R_{B}$ boste najprej uporabili upor $10 \mathrm{k} \Omega$, nato pa drsni upor, ki bo zmožen prenesti dovolj velike tokove.

Razporeditev priključkov na enosmernem pretvorniku si oglejte v tehnični dokumentaciji vezja.

\section{Potek vaje}

- Poiščite tehnični dokument vezja MEE1S0509 in si v njem oglejte razporeditev priključkov.

- Sestavite vezje in na izhod priključite upor $10 \mathrm{k} \Omega$, ki bo predstavljal breme.

- Vhodno napetost spreminjajte od 4,0 do 6,0 V v korakih po 0,1 V. Pri tem merite izhodno napetost.

- Vhodno napetost nastavite na $5 \mathrm{~V}$. Kot breme vzemite drsni upor $330 \Omega$, ki ga spreminjate, da dobite tokove od 80 do $120 \mathrm{~mA}$ v korakih po $5 \mathrm{~mA}$. Pri tem merite izhodno napetost.

- Nastavite vhodno napetost $5 \mathrm{~V}$. Izmerite vse potrebne veličine za izračun izkoristka pri bremenih približno $1 \mathrm{k} \Omega, 330 \Omega$ in $100 \Omega$. V vseh primerih izračunajte izkoristek.

- Narišite grafa za obe zgornji meritvi.

- Opravite izračune in odgovorite na dodatna vprašanja. 


\section{Meritve in rezultati}

Tabela 8: Meritve odvisnosti izhodne napetosti od vhodne napetosti $\left(R_{B}=10 \mathrm{k} \Omega\right)$

\begin{tabular}{|l|l||l|l|}
\hline$U_{v h}[\mathrm{~V}]$ & $U_{i z h}[\mathrm{~V}]$ & $U_{v h}[\mathrm{~V}]$ & $U_{i z h}[\mathrm{~V}]$ \\
\hline \hline & & & \\
\hline & & & \\
\hline & & & \\
\hline & & & \\
\hline & & & \\
\hline & & & \\
\hline & & & \\
\hline & & & \\
\hline & & & \\
\hline & & & \\
\hline
\end{tabular}

Tabela 9: Meritve odvisnosti izhodne napetosti od bremenskega toka $\left(U_{v h}=5 \mathrm{~V}\right)$

\begin{tabular}{|c|c||c|c|}
\hline$I_{i z h}[\mathrm{~mA}]$ & $U_{i z h}[\mathrm{~V}]$ & $I_{i z h}[\mathrm{~mA}]$ & $U_{i z h}[\mathrm{~V}]$ \\
\hline \hline & & & \\
\hline & & & \\
\hline & & & \\
\hline & & & \\
\hline
\end{tabular}

Tabela 10: Podatki za meritev izkoristka

\begin{tabular}{|c|c|c|c|c|}
\hline $\mathrm{R}[\Omega]$ & $U_{v h}[\mathrm{~V}]$ & $I_{v h}[\mathrm{~mA}]$ & $U_{i z h}[\mathrm{~V}]$ & $I_{i z h}[\mathrm{~mA}]$ \\
\hline \hline & & & & \\
\hline & & & & \\
\hline & & & & \\
\hline
\end{tabular}

Koliko je izkoristek pri bremenu $1 \mathrm{k} \Omega$ ?

\section{Odgovor:}

Koliko je izkoristek pri bremenu $330 \Omega$ ?

\section{Odgovor:}

Koliko je izkoristek pri bremenu $100 \Omega$ ?

\section{Odgovor:}


Narišite grafa na podlagi meritev $\mathrm{v}$ tabelah 8 in 9.

\begin{tabular}{|l|l|l|l|l|l|l|l|l|l|l|l|l|}
\hline & & & &
\end{tabular}

Slika 15: Odvisnost izhodne napetosti od vhodne napetosti

\begin{tabular}{|l|l|l|l|l|l|l|l|l|l|l|l|l|}
\hline & & &
\end{tabular}

Slika 16: Odvisnost izhodne napetosti od bremenskega toka 


\section{Izračuni in dodatna vprašanja}

- Izračunajte faktor pretvorbe med vhodno in izhodno napetostjo.

- Za vsako meritev za izračun izkoristka izračunajte še neizkoriščeno moč (tj. moč, ki se troši na pretvorniku) in komentirajte odvisnost izkoristka od bremena. 


\section{Naloga 7: Preklopni časi optičnega povezovalnika}

Navodilo naloge: Sestavite vezje za merjenje preklopnih časov optičnega povezovalnika in izmerite odvisnost vklopnega časa od diodnega toka ter izklopnega časa od bremena.

\section{Uvod}

Optični povezovalnik (angl. optocoupler, opto-isolator, photocoupler ali optical isolator) je elektronski element, ki opravlja dve pretvorbi. Prva pretvorba je električno-optična (svetleča dioda LED), kjer vhodni električni tok $\left(I_{F}\right)$ povzroča oddajanje svetlobe. Druga pretvorba je optičnoelektrična (optično občutljiv element). Optični povezovalniki lahko vsebujejo različne optično občutljive elemente. $\mathrm{V}$ primeru povezovalnika $4 \mathrm{~N} 35$ je to fototranzistor, ki ima bazo ne le občutljivo na svetlobo, ampak jo ima tudi vezano na zunanji priključek vezja. S tem lahko tranzistor odpremo ali preko svetlobe ali preko električnega toka na bazo.

Ker optični povezovalnik prenaša signale s svetlobo, ga uporabljamo za galvansko ločitev elektronskih sklopov in tako zaščitimo posamezne elektronske sklope pred visokimi napetostmi v drugih sklopih. Druga možnost uporabe je prenašanje podatkov med dvema elektronskima vezjema, ki sta na različnih električnih potencialih in zato med njima nočemo galvanske povezave.

V tej nalogi boste preverili delovanje tako vhodnega dela kot delovanje izhodnega dela optičnega povezovalnika. Izmerili boste vhodno karakteristiko povezovalnika (odvisnost vhodnega toka od vhodne napetosti) in istočasno še vklopne čase povezovalnika (čas, v katerem izhod povezovalnika preide iz zaprtega stanja v odprto stanje) v odvisnosti od vhodnega toka.

$\mathrm{V}$ drugem delu naloge preverite delovanje izhodnega dela optičnega povezovalnika. Izmerili boste upornost na izhodnem delu v odprtem stanju ter izklopne čase povezovalnika (čas, v katerem izhod povezovalnika preide iz odprtega stanja v zaprto stanje) v odvisnosti od bremena.

Kadar merimo preklopne čase, merimo čas, ki je potreben, da sprememba na vhodu vezja oz. elementa povzroči spremembo na izhodu. Preklopni čas je sestavljen iz časa zakasnitve in časa naraščanja oz. padanja izhodnega signala. Poznati moramo celotno spremembo na izhodu. Čas zakasnitve je čas od trenutka spremembe na vhodu do trenutka, ko signal na izhodu doseže $10 \%$ celotne spremembe. Čas naraščanja oz. padanja pa je čas od trenutka, ko signal na izhodu doseže $10 \%$ spremembe, do trenutka, ko doseže $90 \%$ spremembe. Preklopni čas je vsota teh dveh časov.

Primer: izhodna napetost se spremeni z $0 \mathrm{~V}$ na $5 \mathrm{~V}$. Čas zakasnitve je čas od spremembe na vhodu do trenutka, ko napetost na izhodu naraste na $0,5 \mathrm{~V}$. Čas naraščanja je čas, ko napetost narašča od $0,5 \mathrm{~V}$ do $4,5 \mathrm{~V}$. Preklopni čas je vsota teh časov oz. čas od spremembe na vhodu do trenutka, ko napetost doseže $4,5 \mathrm{~V}$. 


\section{Shema}

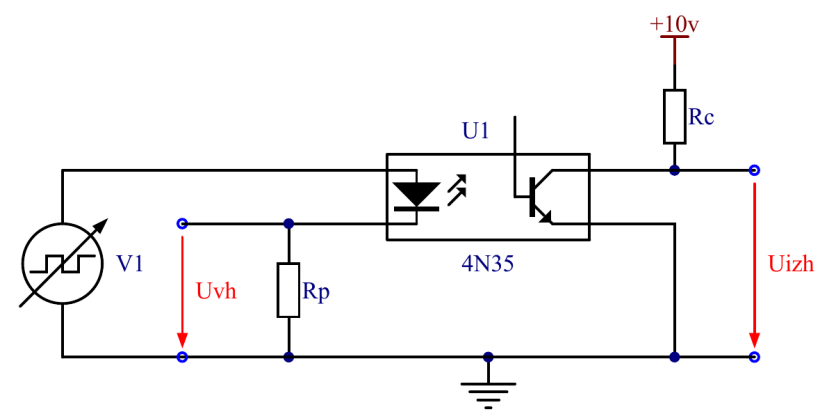

Slika 17: Vezje z optičnim povezovalnikom za merjenje preklopnih časov

Vezje za merjenje preklopnih časov je prikazano na sliki 17. Za pravilno priključitev optičnega povezovalnika poglejte njegovo dokumentacijo. S funkcijskim generatorjem tvorimo vhodni pravokotni signal, katerega frekvenca mora biti dovolj nizka, da v vsaki polperiodi signala optični povezovalnik popolnoma preide iz odprtega stanja $\mathrm{v}$ zaprto oz. iz zaprtega $\mathrm{v}$ odprto.

Vhodno in izhodno napetost opazujemo z osciloskopom. Na podlagi poteka napetosti na uporu $R_{p}$ zaznamo trenutek spremembe vhodnega signala in velikost vhodnega toka $I_{F}$. Upor izberemo primerno, da lahko s funkcijskim generatorjem dosežemo maksimalni vhodni tok, ki ga podaja proizvajalec optičnega povezovalnika. Bremenski upor $R_{C}$ spreminjamo po navodilih naloge uporabite uporovno dekado. Na podlagi poteka izhodne napetosti določamo vklopne in izklopne čase.

Upoštevati moramo način vezave izhoda optičnega povezovalnika. Z njim namreč ob vklopu delamo na izhodu stik proti masi. To pomeni, da bomo vklopni čas merili pri padanju napetosti na izhodu, izklopni čas pa pri naraščanju napetosti na izhodu.

\section{Potek vaje}

- Sestavite merilno vezje, kjer za upor $R_{C}$ uporabite uporovno dekado. V prvem delu vaje nastavite $R_{C}=5 \mathrm{k} \Omega$.

- Na funkcijskem generatorju nastavite pravokotno obliko izhodnega signala, frekvenco 100 $\mathrm{Hz}$ in nizki nivo napetosti $0 \mathrm{~V}$.

- Spreminjajte visoki nivo napetosti tako, da dosežete zaželene vhodne tokove (glej tabelo).

- Zabeležite napetost na funkcijskem generatorju $\left(U_{F G}\right)$, izračunajte vhodno napetost na optičnem povezovalniku $\left(U_{F}\right)$ in izmerite vklopni čas $\left(t_{o n}\right)$ optičnega povezovalnika za vsako izmed navedenih vrednosti vhodnega toka.

- Narišite karakteristiko odvisnosti vklopnega časa od vhodnega toka.

- Izmerite izklopni čas za vsako navedeno vrednost bremena pri toku $I_{F}=20 \mathrm{~mA}$.

- Narišite karakteristiko odvisnosti izklopnega časa od bremena.

- Izmerite upornost optičnega povezovalnika v odprtem stanju. 


\section{Meritve in rezultati}

Tabela 11: Meritve vklopnih časov optičnega povezovalnika

\begin{tabular}{|c|c|c|c|}
\hline$I_{F}[\mathrm{~mA}]$ & $U_{F G}[\mathrm{~V}]$ & $U_{F}[\mathrm{~V}]$ & $t_{\text {on }}[\mu \mathrm{s}]$ \\
\hline \hline 10 & & & \\
\hline 15 & & & \\
\hline 20 & & & \\
\hline 25 & & & \\
\hline 30 & & & \\
\hline 35 & & & \\
\hline 40 & & & \\
\hline 45 & & & \\
\hline 50 & & & \\
\hline
\end{tabular}

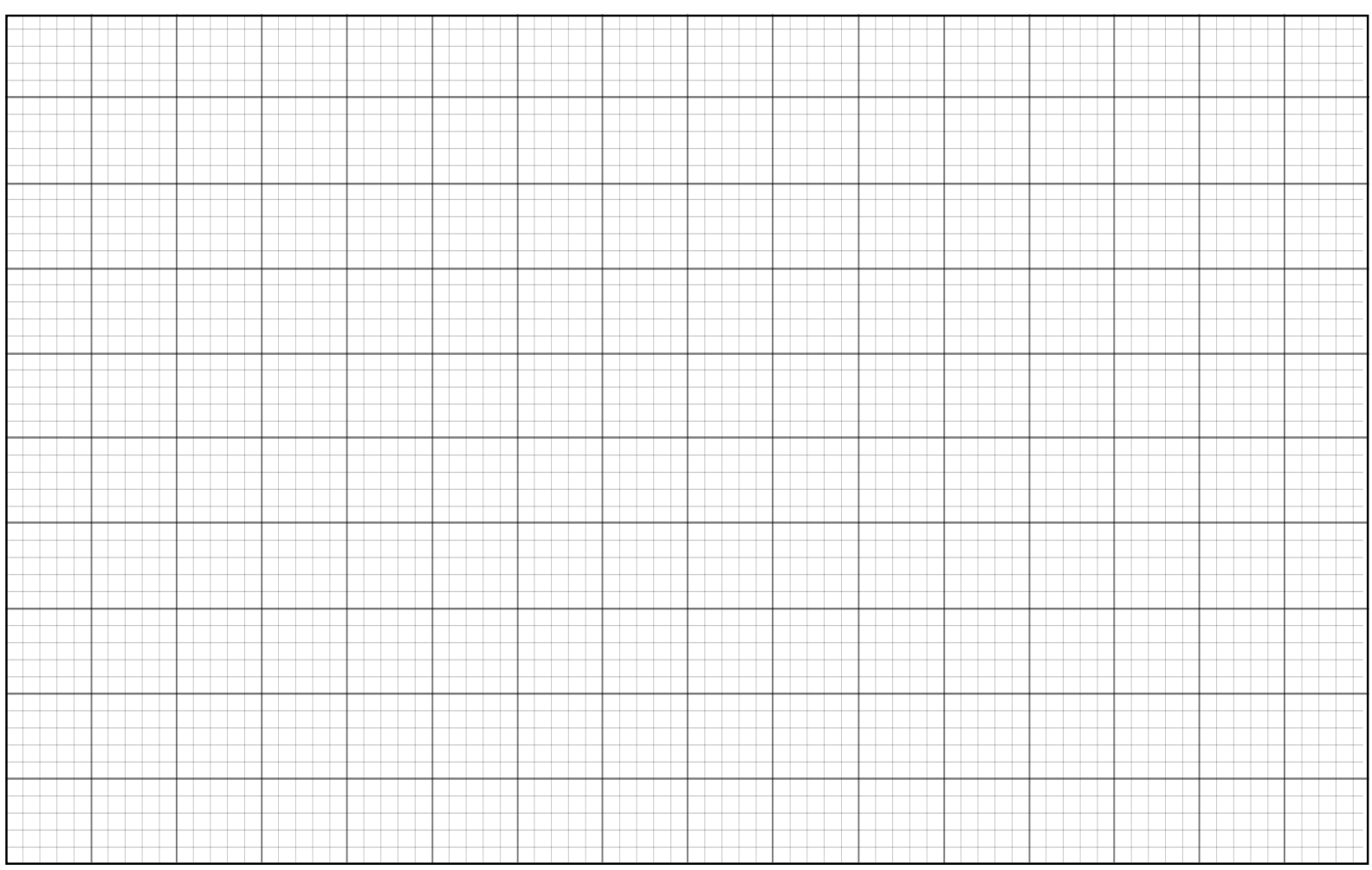

Slika 18: Odvisnost vklopnega časa od diodnega toka $I_{F}$ 
Tabela 12: Meritve izklopnih časov optičnega povezovalnika

\begin{tabular}{|c|c||c|c|}
\hline$R_{C}[\mathrm{k} \Omega]$ & $t_{\text {off }}[\mu \mathrm{s}]$ & $R_{C}[\mathrm{k} \Omega]$ & $t_{\text {off }}[\mu \mathrm{s}]$ \\
\hline \hline 1,0 & & 3,5 & \\
\hline 1,5 & & 4,0 & \\
\hline 2,0 & & 4,5 & \\
\hline 2,5 & & 5,0 & \\
\hline 3,0 & & & \\
\hline
\end{tabular}

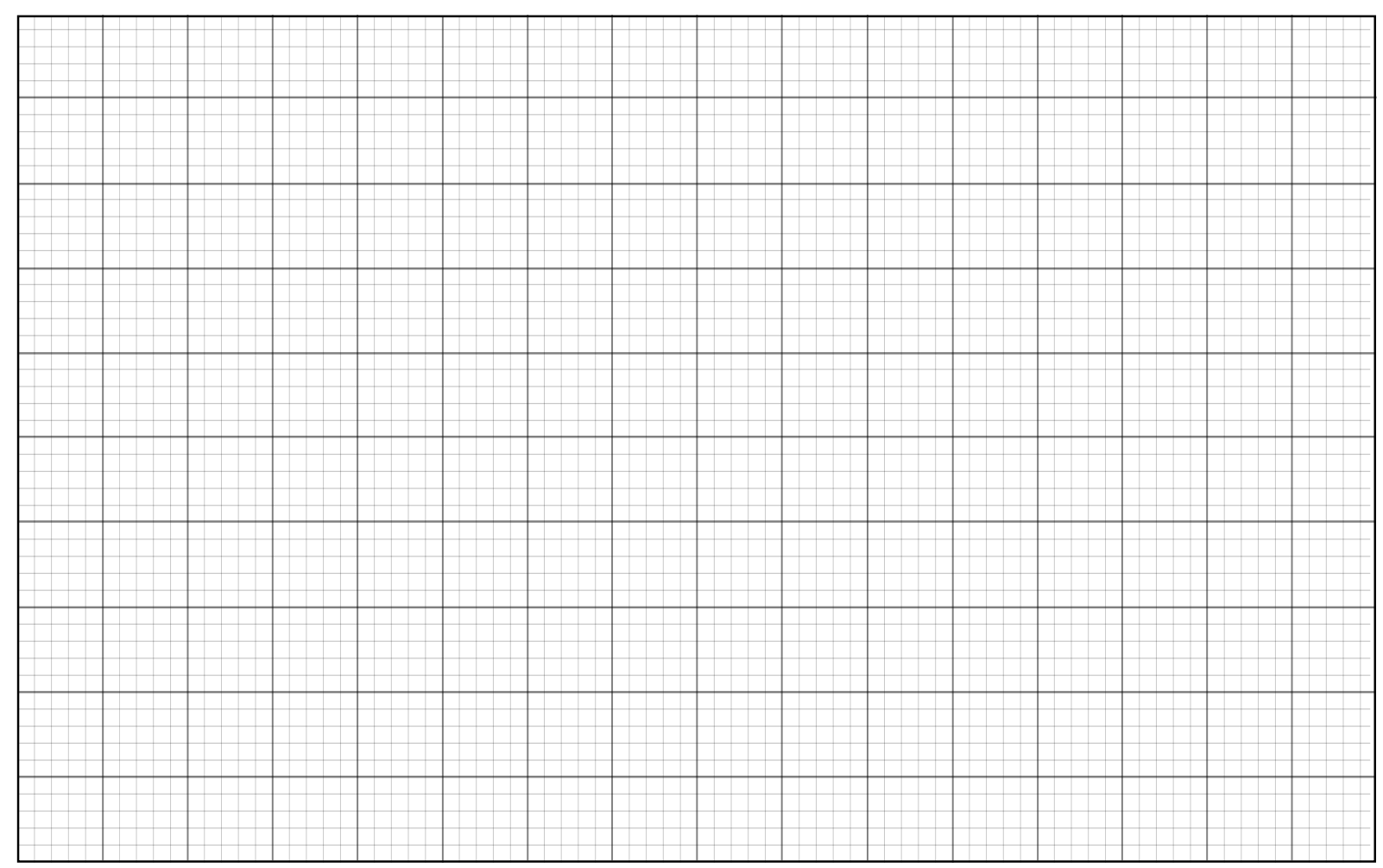

Slika 19: Odvisnost izklopnega časa od bremena

Izmerite padec napetosti na optičnem povezovalniku v odprtem stanju pri toku $I_{F}=20 \mathrm{~mA}$ in uporu $R_{C}=5 \mathrm{k} \Omega$. Iz meritve izračunajte upornost v odprtem stanju: 


\section{Naloga 8: Uporaba senzorjev in mikrokrmilnika}

Navodilo naloge: Uporabite analogne in digitalne senzorje ter mikrokrmilnika, da izmerite temperaturo in vlago $\mathrm{v}$ prostoru.

\section{Uvod}

V vgrajenih sistemih uporabljamo analogne in digitalne senzorje za merjenje raznih veličin. Te so lahko okoljski podatki, kot so temperatura in vlaga, podatki o gibanju, kjer uporabimo MEMSelemente, in druge veličine. $\mathrm{Z}$ mikrokrmilnikom zajemamo podatke iz senzorjev in jih nato preoblikujemo v razumljivo obliko (npr. napetost na izhodu analognega senzorja temperature pretvorimo v podatek, izražen v stopinjah Celzija).

Za zajemanje in obdelavo podatkov iz analognih senzorjev potrebujemo analogno-digitalni pretvornik (ADC). Za to pretvorbo lahko uporabimo namensko integrirano vezje, vendar pa večina sodobnih mikrokrmilnikov že ima vgrajene ADC-je. Da jih lahko uporabljamo, moramo razumeti njihov izhodni podatek. $\mathrm{V}$ tej vaji boste imeli pripravljen program za mikrokrmilnik, kjer bo že implementirana uporaba ADC in bo na voljo njegov izhodni podatek.

Za razumevanje izhodnega podatka ADC-ja moramo poznati referenčno napetost in ločljivost pretvornika. Pogosta izbira za referenčno napetost je napajalna napetost mikrokrmilnika. V našem primeru bo to $3,3 \mathrm{~V}$. Ločljivost pretvornika je odvisna od števila bitov v izhodnem podatku $n$. Možne izhodne vrednosti ADC-ja so števila od 0 do $2^{n}-1$. Izhodna vrednost 0 ustreza napetosti $0 \mathrm{~V}$, vrednost $2^{n}-1$ pa referenčni napetosti $U_{r e f}$. Naj bo $A$ izhodni podatek, potem lahko vhodno napetost $\mathrm{v}$ ADC izračunamo:

$$
U_{v h}=\frac{A}{2^{n}} U_{r e f} .
$$

Nadaljnja obdelava je odvisna od samega senzorja, tj. od povezave med izhodno napetostjo senzorja in merjeno veličino. Povezavo najdemo v tehnični dokumentaciji senzorja.

Digitalni senzorji se priključijo na mikrokrmilnik preko različnih vrst digitalnih komunikacijskih vodil, kot so $\mathrm{I}^{2} \mathrm{C}$ in SPI. Pri teh senzorjih se pretvorba $\mathrm{v}$ digitalno vrednost izvede že $\mathrm{v}$ samem senzorju, nato pa jo je potrebno še prenesti v mikrokrmilnik. $\mathrm{V}$ tej vaji boste imeli pripravljen program za mikrokrmilnik, kjer bo vrednost iz senzorja že prenesena v mikrokrmilnik.

Nadaljnja obdelava podatkov bo ponovno odvisna od samega senzorja, tj. v kakšni obliki je vrednost merjene veličine zakodirana v podatkih, ki jih pošlje senzor na mikrokrmilnik. Ustrezne informacije ponovno najdemo $\mathrm{v}$ tehnični dokumentaciji senzorja. 


\section{Shema}

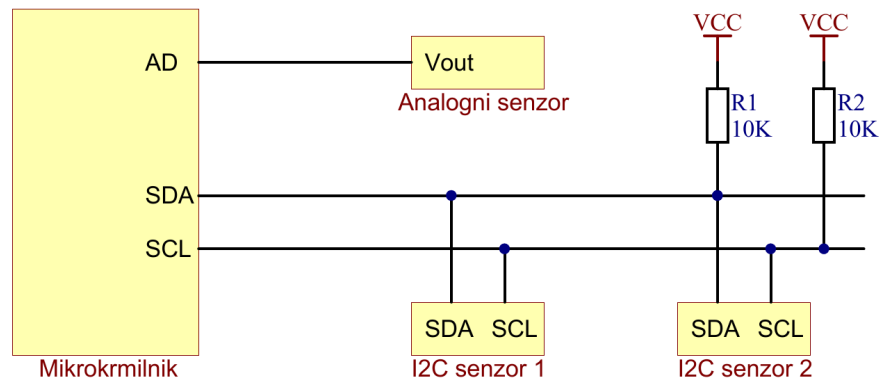

Slika 20: Princip povezovanja analognih senzorjev in digitalnih senzorjev $\mathrm{z}$ vodilom $\mathrm{I}^{2} \mathrm{C}$ na tipičen mikrokrmilnik z vgrajenimi ADC-ji

Slika 20 prikazuje tipični način povezovanja analognih senzorjev in digitalnih senzorjev z vodilom $\mathrm{I}^{2} \mathrm{C}$ na mikrokrmilnik. $\mathrm{V}$ primeru naše vaje bomo uporabili mikrokrmilnik Microchip Technology SAM4SD32C, ki vsebuje analogno-digitalni pretvornik z ločljivostjo 12 bitov.

Uporabili bomo analogni senzor MCP9701 za merjenje temperature in digitalni senzor SHT21, ki meri temperaturo in vlago ter se poveže z mikrokrmilnikom preko vodila $\mathrm{I}^{2} \mathrm{C}$. Ker vse naprave na tem vodilu uporabljajo izhode tipa odprti kolektor (open collector) oz. odprti ponor (open drain), v vezje vključimo tudi dvižne (pull-up) upore, s katerimi zagotovimo pravilno delovanje komunikacije.

\section{Potek vaje}

- Preučite tehnično dokumentacijo senzorjev MCP9701 in SHT21 - predvsem odvisnost izhodne napetosti oz. način kodiranja merjenih veličin.

- Izpeljite izraz za pretvorbo izhodnega podatka ADC-ja v napetost.

- Odprite pripravljen projekt za programiranje mikrokrmilnika ter vanj zapišite manjkajočo kodo za:

- pretvorbo merjene napetosti $\mathrm{v}$ temperaturo,

- pretvorbo digitalnega podatka $\mathrm{v}$ temperaturo in vlago.

- Preverite delovanje in prepišite kodo v poročilo.

- $\mathrm{Z}$ analognimi in digitalnim senzorjem izmerite temperaturo in vlago.

- Opravite izračune in odgovorite na dodatna vprašanja. 


\section{Meritve in rezultati}

Programska koda za pretvorbo podatka ADC v temperaturo:

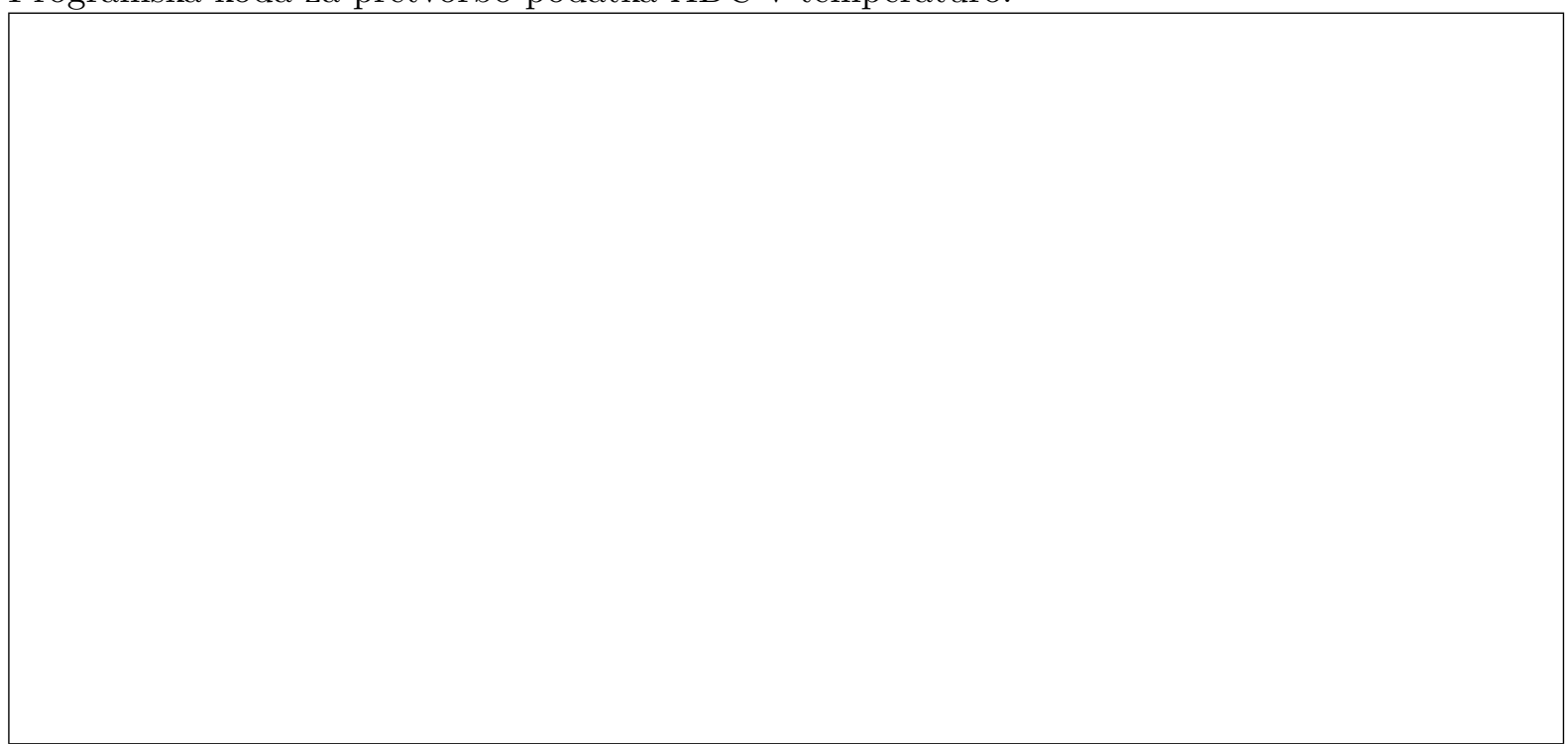

Programska koda za pretvorbo podatkov iz digitalnega senzorja:

Koliko znaša temperatura, izmerjena z analognim senzorjem?

\section{Odgovor:}

Koliko znaša temperatura, izmerjena z digitalnim senzorjem?

\section{Odgovor:}

Koliko znaša vlaga, izmerjena z digitalnim senzorjem?

\section{Odgovor:}




\section{Izračuni in dodatna vprašanja}

- Koliko je kvantizacijska napaka pri merjenju temperature z analognim senzorjem (rezultat izrazi $\left.{ }^{\circ} \mathrm{C}\right)$ ?

- Koliko je ločljivost merjenja temperature in vlage pri digitalnem senzorju? 


\section{Naloga 9: Kapacitivni pretvorniki}

Navodilo naloge: Z razvojno ploščico, ki vsebuje kapacitivni pretvornik FDC1004, izmerite odvisnost kapacitivnosti od razdalje prsta do merilne elektrode in od nivoja tekočine nad merilno elektrodo.

\section{Razvojna ploščica}

Razvojna ploščica je sestavljena iz treh sklopov. Prvi sklop je komunikacijski pretvornik med komunikacijo USB in $\mathrm{I}^{2} \mathrm{C}$. Ta je potreben, da lahko ploščico priključimo neposredno na USBpriključek osebnega računalnika. Drugi sklop vsebuje integrirano vezje TI FDC1004, ki opravlja meritev kapacitivnosti in ustrezne podatke posreduje na PC. V tretjem sklopu sta dve elektrodi, na katerih merimo kapacitivnost.

\section{Potek vaje}

1. Priključite ploščico na PC. Zaženite programsko opremo za zajemanje podatkov in izberite neprekinjeno zajemanje podatkov. Preverite delovanje z dotiki levega in desnega polja na ploščici.

2. Izmerite kapacitivnosti glede na nadaljnja navodila in narišite graf.

\section{Meritve in rezultati}

Testna ploščica ima dve polji za dotik (LEFT in RIGHT). Katerima od štirih kanalov ustrezata ti dve polji?

\section{Odgovor:}

Koliko je izmerjena kapacitivnost na levem polju, kadar se ga ne dotikamo?

\section{Odgovor:}

Koliko je izmerjena kapacitivnost na desnem polju, kadar se ga ne dotikamo?

\section{Odgovor:}

Koliko je izmerjena kapacitivnost na levem polju, kadar se ga dotikamo?

\section{Odgovor:}

Koliko je izmerjena kapacitivnost na desnem polju, kadar se ga dotikamo?

\section{Odgovor:}


V programu preberite izmerjeno kapacitivnost, kadar prst približate obema poljema do določene razdalje. Rezultate zapišite $\mathrm{v}$ tabelo.

Tabela 13: Meritev kapacitivnosti glede na oddaljenost prsta

\begin{tabular}{|c|c|c|}
\hline Oddaljenost $[\mathrm{mm}]$ & Kapacitivnost LEFT $[\mathrm{pF}]$ & Kapacitivnost RIGHT $[\mathrm{pF}]$ \\
\hline \hline 2 & & \\
\hline 4 & & \\
\hline 6 & & \\
\hline
\end{tabular}

Na polje dajte prazen plastičen kozarec. Izmerite kapacitivnost pri kozarcu, ki je prazen, poln eno četrtino, poln polovico, poln tri četrtine in poln do vrha. Vrednosti zapišite v tabelo. Narišite graf odvisnosti kapacitivnosti od deleža vode.

Tabela 14: Meritev kapacitivnosti glede na količino vode

\begin{tabular}{|c|c|}
\hline Delež vode $\mathrm{v}$ kozarcu & Izmerjena kapacitivnost $[\mathrm{pF}]$ \\
\hline \hline 0 & \\
\hline $1 / 4$ & \\
\hline $2 / 4$ & \\
\hline $3 / 4$ & \\
\hline 1 & \\
\hline
\end{tabular}

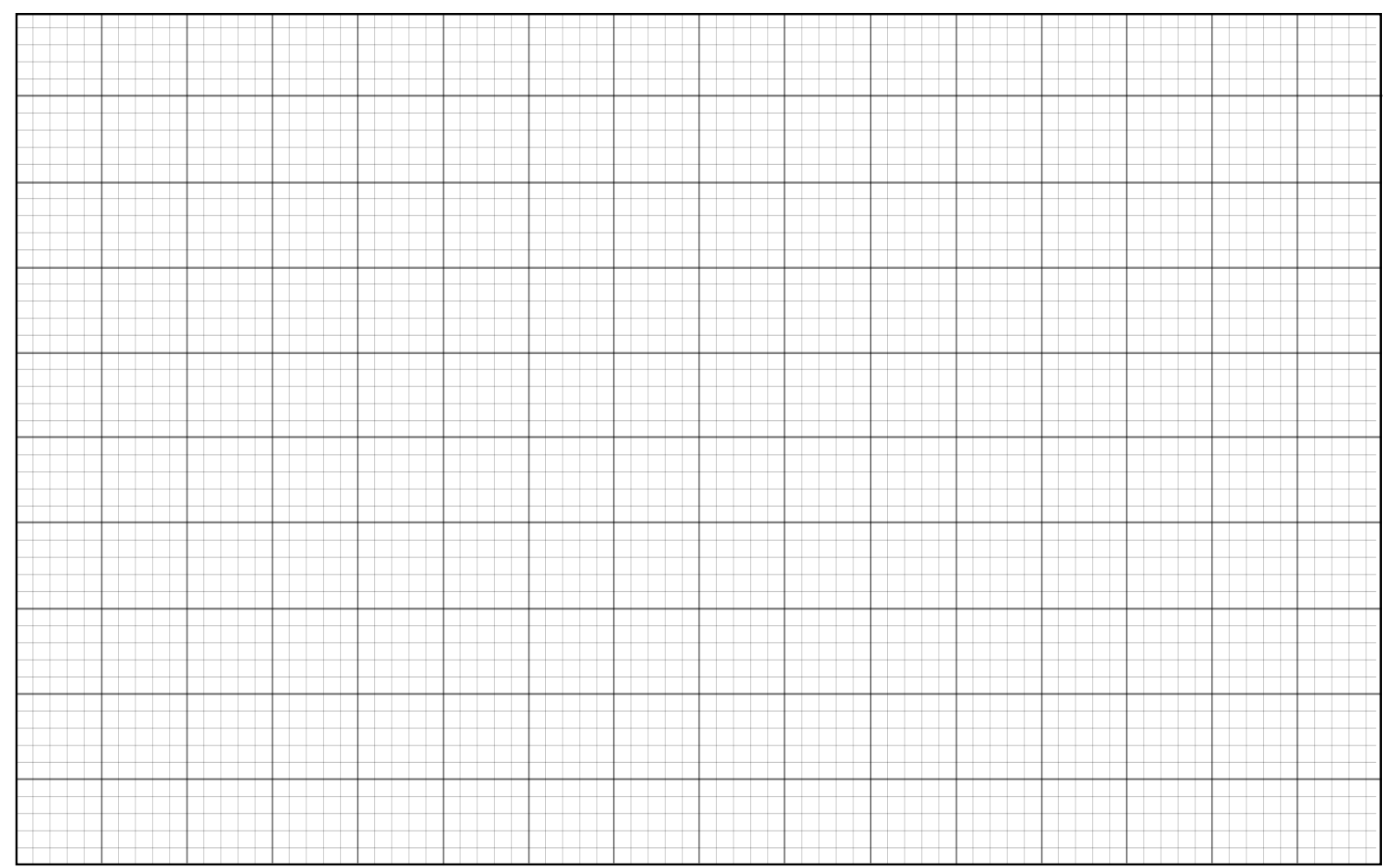

Slika 21: Odvisnost kapacitivnosti od količine vode

\begin{tabular}{|l|l|}
\hline Točke: & $/ 5$ \\
\hline
\end{tabular}




\section{Naloga 10: Pretok tekočine}

Navodilo naloge: Izmerite pretok tekočine skozi cev v odvisnosti od napajalne napetosti pretočne črpalke, ki poganja tekočino. Pretok tekočine merite posredno z meritvijo periode impulzov iz senzorja pretoka. Za meritve časa trajanja impulza uporabite osciloskop.

\section{Uvod}

Senzor pretoka tekočin je s cevjo povezan s pretočno črpalko in rezervoarjem tekočine. Črpalka vleče tekočino iz rezervoarja in jo potiska skozi senzor pretoka nazaj v rezervoar. Senzor pretoka tekočin je dajalnik impulzov s konstantnim številom impulzov na volumen tekočine. To razmerje znaša 1,8 impulza na $1 \mathrm{ml}$ tekočine. Njegov izhod je izveden tako, da omogoča prilagoditev visokega nivoja izhodne napetosti. To pa tudi pomeni, da na njegovem izhodu potrebujemo še dvižni (pull-up) upor, vezan proti napajalni napetosti.

\section{Shema}

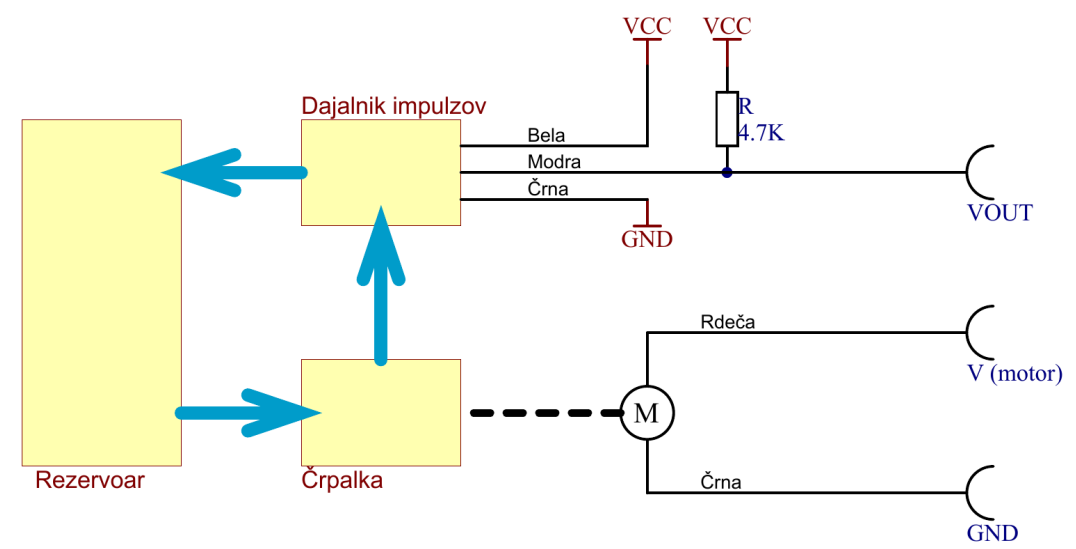

Slika 22: Vezalna shema za pretvornik pretoka tekočine

\section{Potek vaje}

- Sestavite vezje in priključite napajanje $V_{c c}=5 \mathrm{~V}$.

- Izmerite odvisnost dolžine periode impulza $t_{s}$ na izhodu od napetosti $U$ na pretočni črpalki. Napajanje črpalke $U$ spreminjajte od $2 \mathrm{~V}$ do $7 \mathrm{~V}$ v korakih po $0,5 \mathrm{~V}$.

- Izmerjene vrednosti preračunajte v frekvenco in nato v pretok tekočine.

- Narišite graf odvisnosti pretoka $Q_{P}$ od napetosti $U$ na pretočni črpalki. 


\section{Meritve in rezultati}

Tabela 15: Meritve in izračuni za merilnik pretoka tekočin

\begin{tabular}{|l|l|l|l|}
\hline$U[\mathrm{~V}]$ & $t_{s}[\mathrm{~s}]$ & $f_{s}[\mathrm{~Hz}]$ & $Q_{p}[\mathrm{ml} / \mathrm{s}]$ \\
\hline \hline & & & \\
\hline & & & \\
\hline & & & \\
\hline & & & \\
\hline & & & \\
\hline & & & \\
\hline & & & \\
\hline & & & \\
\hline & & & \\
\hline
\end{tabular}

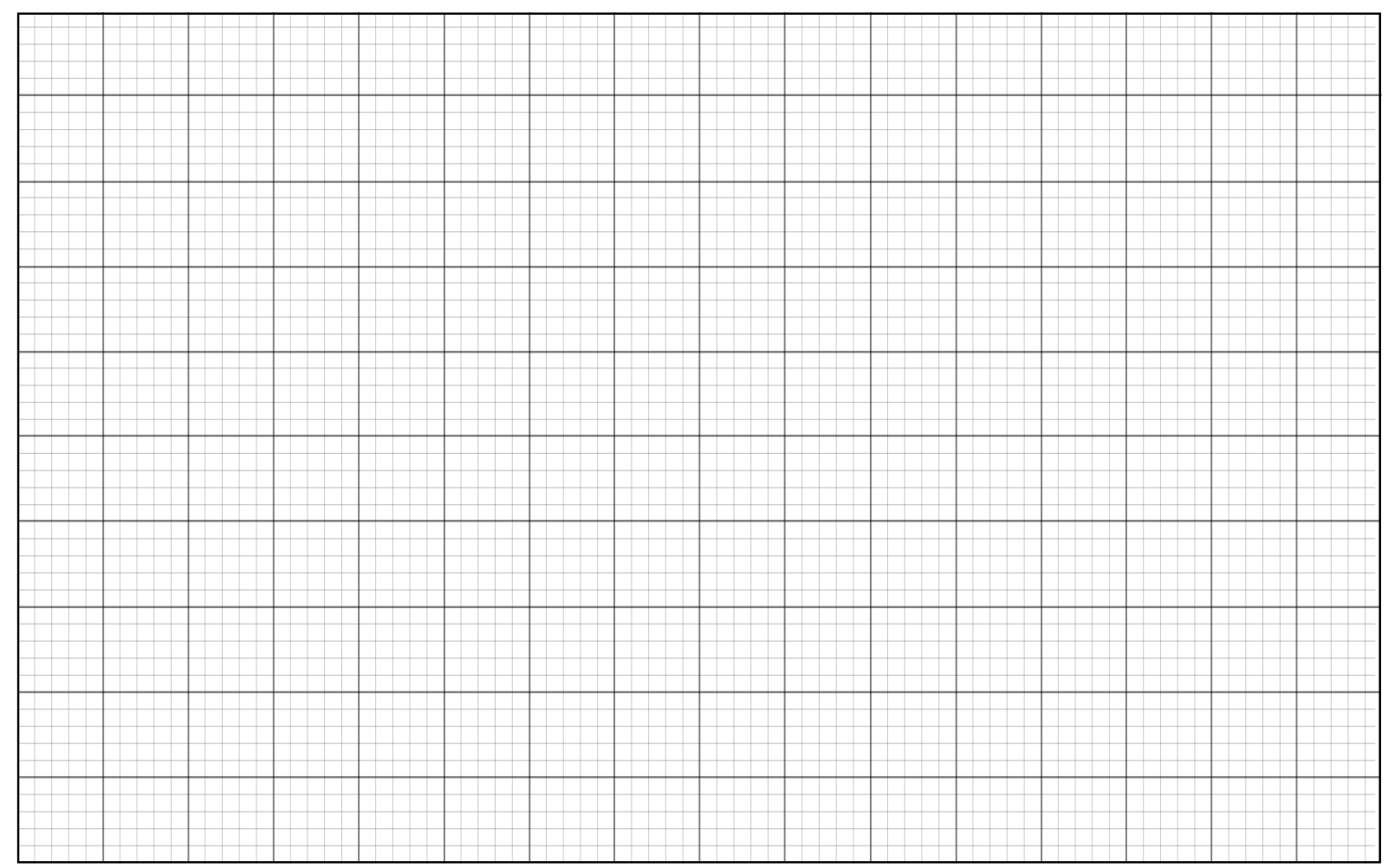

Slika 23: Odvisnost pretoka tekočine od napajalne napetosti črpalke 


\section{Naloga 11: Gostota magnetnega pretoka}

Navodilo naloge: S Hallovo sondo izmerite gostoto magnetnega pretoka $B$ v feritnem jedru v odvisnosti od enosmernega toka v navitju tuljave. Gostoto magnetnega pretoka $B$ določite z merjenjem izhodne napetosti sonde $U_{i z h}$.

\section{Uvod}

Hallova sonda je nameščena v zračno režo feritnega jedra, okoli katerega je navita tuljava s 1000 ovoji. Enosmerni tok skozi navitje tuljave povzroči gostoto magnetnega pretoka $B \mathrm{v}$ zračni reži feritnega jedra, ki jo tipamo s Hallovo sondo. Napetost Hallove sonde se ojača z operacijskim ojačevalnikom, tako da je razmerje med magnetno gostoto $B$ in izhodno napetostjo $80 \mathrm{mT} / \mathrm{V}$.

Zaradi enosmernega toka prihaja do magnetenja feritnega jedra in ga je tako potrebno predhodno razmagnetiti. Razmagnetenje feritnega jedra je potrebno izvesti pred začetkom meritev. To storimo z izmeničnim signalom na navitju tuljave, katerega amplitudo je potrebno najprej nastaviti na maksimalno vrednost, ki jo zmore funkcijski generator, in nato zmanjševati proti nič v času nekaj sekund. Frekvenca signala naj bo $50 \mathrm{~Hz}$.

\section{Shema}

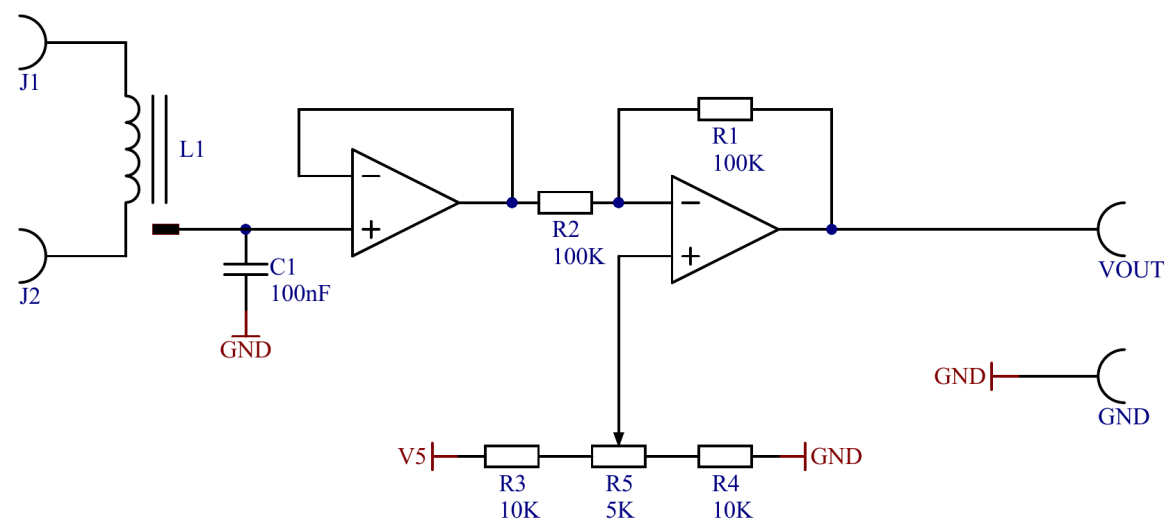

Slika 24: Vezalna shema za magnetni pretvornik

\section{Potek vaje}

- Sestavite vezje in izvedite razmagnetenje.

- Izmerite odvisnost izhodne napetosti $U_{i z h}$ od enosmernega toka $I$ skozi tuljavo ter izračunajte gostoto magnetnega pretoka $B$.

- Narišite graf odvisnosti gostote magnetnega pretoka $B$ od toka $I$. 


\section{Meritve in rezultati}

Tabela 16: Meritve in izračuni gostote magnetnega pretoka

\begin{tabular}{|c|c|c|}
\hline$I[\mathrm{~mA}]$ & $U_{i z h}[\mathrm{~V}]$ & $B[\mathrm{mT}]$ \\
\hline \hline 0 & & \\
\hline \hline 100 & & \\
\hline 200 & & \\
\hline 300 & & \\
\hline 400 & & \\
\hline 500 & & \\
\hline 600 & & \\
\hline-100 & & \\
\hline-200 & & \\
\hline-300 & & \\
\hline-400 & & \\
\hline-500 & & \\
\hline-600 & & \\
\hline & & \\
\hline
\end{tabular}

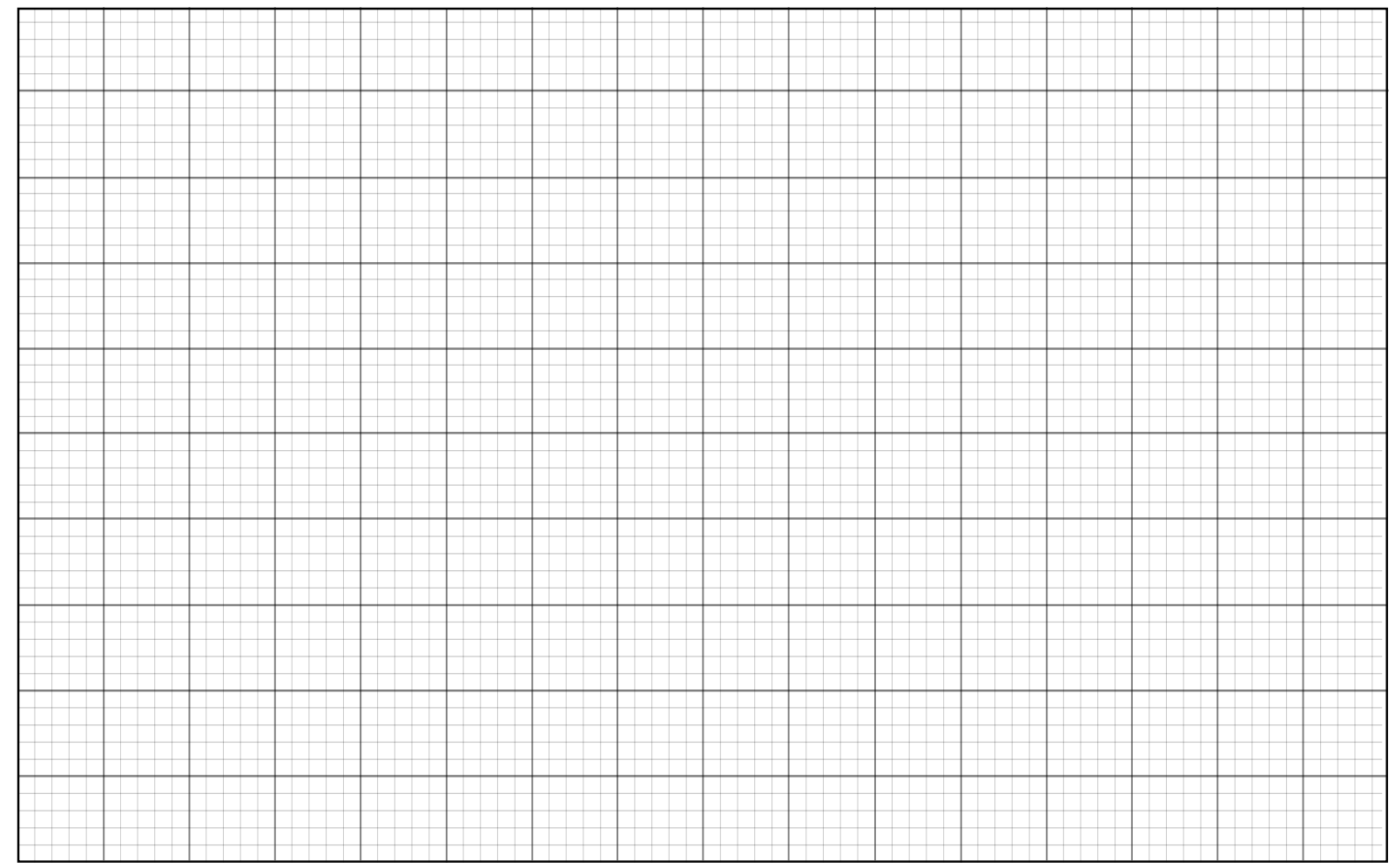

Slika 25: Odvisnost magnetnega pretoka od vhodnega toka 


\section{Naloga 12: Merjenje vpadne svetlobe}

Navodilo naloge: Na osnovi napetostnega delilnika, ki vsebuje fotoupor, sestavite preprosto vezje za zaznavanje količine vpadne svetlobe. Preverite njegovo delovanje in izmerite njegovo karakteristiko.

\section{Uvod}

Fotoupor (LDR, angl. Light Dependent Resistor) je polprevodniški element, ki je v temi neprevoden. S povečanjem vpadne svetlobe nanj se v njem poveča število prostih nosilcev naboja in njegova prevodnost se poveča. Fotoupor lahko uporabljamo za zaznavanje osvetljenosti, če na posreden ali neposreden način merimo njegovo upornost oz. prevodnost. V tej nalogi bomo sestavili napetostni delilnik, ki vsebuje en fiksni upor z vrednostjo $1 \mathrm{k} \Omega$ in fotoupor EXCELITAS TECH VT90N1. V vezje vežite voltmeter in izmerite padec napetosti na fotouporu. Glede na ta padec in napajalno napetost na napetostnem delilniku lahko določimo padec napetosti na drugem uporu, tok skozi oba upora in upornost oz. prevodnost fotoupora.

Delovanje vezja boste preverili tako, da boste fotoupor, ki se nahaja v zaprti cevi, osvetljevali z žarnico, ki se tudi nahaja v cevi. Spreminjali boste napajalno napetost žarnice in merili napetost na napetostnem delilniku.

\section{Shema}

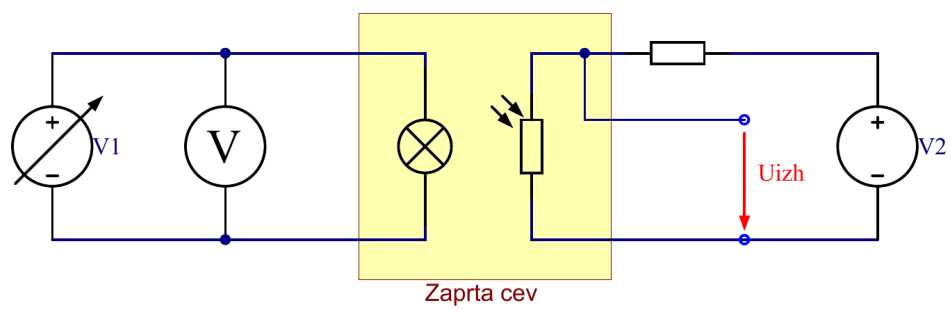

Slika 26: Vezalna shema za svetlobni pretvornik

\section{Potek vaje}

1. Sestavite vezje in priključite napajanje.

2. Spreminjajte napajalno napetost žarnice od $0 \mathrm{~V}$ do $8 \mathrm{~V}$ v korakih po $0,5 \mathrm{~V}$ in merite napetost na napetostnem delilniku.

3. Izračunajte tok skozi delilnik in prevodnost fotoupora.

4. Narišite graf odvisnosti prevodnosti fotoupora od napajalne napetosti žarnice. 


\section{Meritve in rezultati}

Tabela 17: Meritve in izračuni prevodnosti fotoupora

\begin{tabular}{|l|l|l|l|}
\hline$U_{P}[\mathrm{~V}]$ & $U_{i z h}[\mathrm{~V}]$ & $I[\mathrm{~mA}]$ & $G[\mathrm{mS}]$ \\
\hline \hline & & & \\
\hline & & & \\
\hline & & & \\
\hline & & & \\
\hline & & & \\
\hline & & & \\
\hline & & & \\
\hline & & & \\
\hline & & & \\
\hline & & & \\
\hline & & & \\
\hline & & & \\
\hline & & & \\
\hline
\end{tabular}

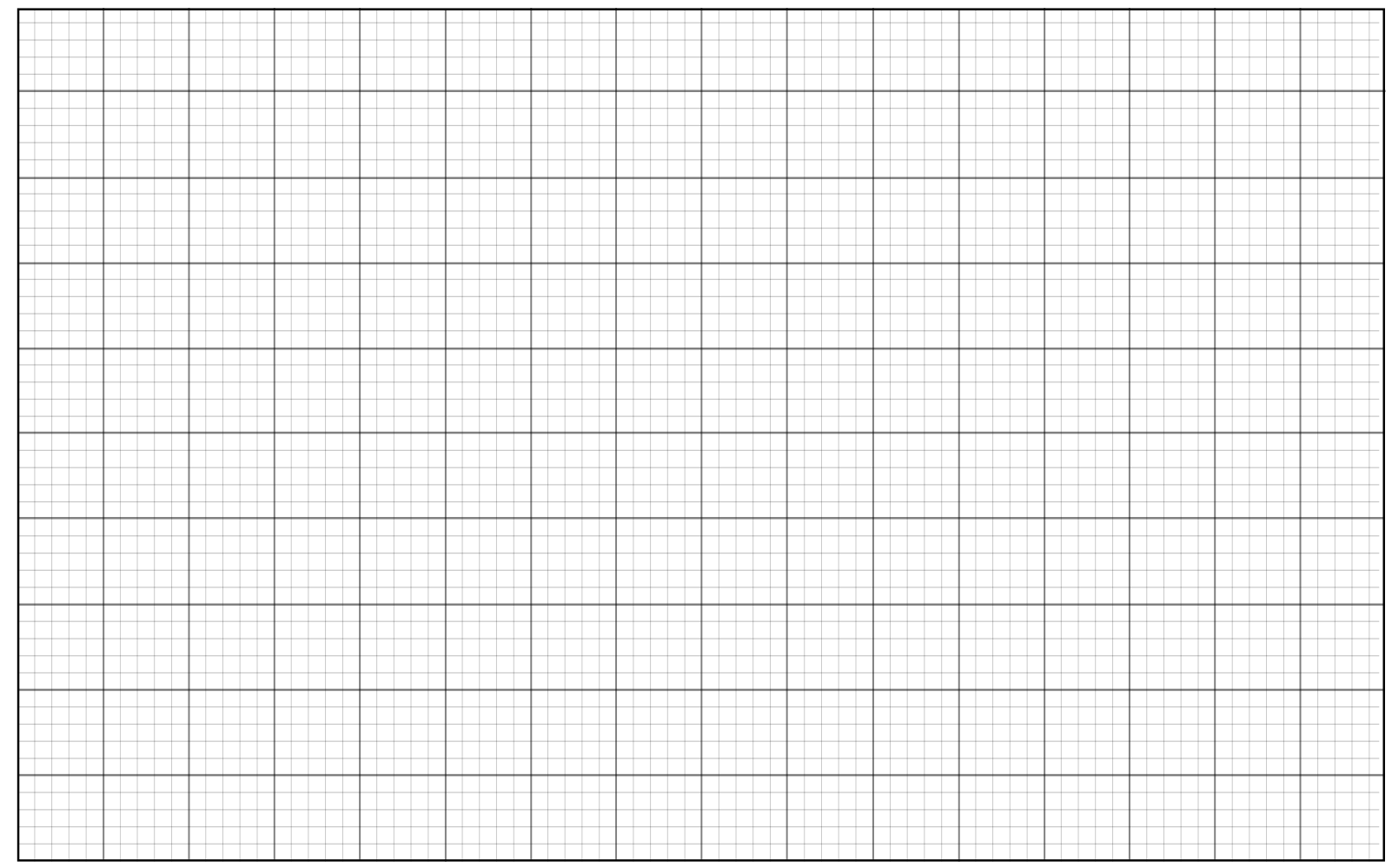

Slika 27: Odvisnost prevodnosti fotoupora od napetosti na žarnici 


\section{Ocena}

Dosežene točke pri nalogah:

\begin{tabular}{|c|c|}
\hline Naloga 1: & Naloga 7: \\
\hline Naloga 2: & Naloga 8: \\
\hline Naloga $3:$ & Naloga 9: \\
\hline Naloga 4: & Naloga 10: \\
\hline Naloga 5: & Naloga 11: \\
\hline Naloga 6: & Naloga 12: \\
\hline
\end{tabular}

Študent: $\quad$ Ime in priimek:

Vpisna številka:

Študijsko leto:

Ocenjevalec: Datum:

Končna ocena (\%):

Podpis: 